\title{
Review \\ The Key Role of the WNT/ $\beta$-Catenin Pathway in Metabolic Reprogramming in Cancers under Normoxic Conditions
}

\author{
Alexandre Vallée ${ }^{1, *(\mathbb{D},}$, Yves Lecarpentier ${ }^{2}$ and Jean-Noël Vallée ${ }^{3,4}$ \\ 1 Department of Clinical Research and Innovation (DRCI), Foch Hospital, 92150 Suresnes, France \\ 2 Centre de Recherche Clinique, Grand Hôpital de l'Est Francilien (GHEF), 6-8 Rue Saint-Fiacre, \\ 77100 Meaux, France; yves.c.lecarpentier@gmail.com \\ 3 Centre Hospitalier Universitaire (CHU) Amiens Picardie, Université Picardie Jules Verne (UPJV), \\ 80054 Amiens, France; valleejn@gmail.com \\ 4 Laboratoire de Mathématiques et Applications (LMA), UMR, CNRS 7348, Université de Poitiers, \\ 86000 Poitiers, France \\ * Correspondence: alexandre.g.vallee@gmail.com
}

check for updates

Citation: Vallée, A.; Lecarpentier, Y.; Vallée, J.-N. The Key Role of the WNT/ $\beta$-Catenin Pathway in Metabolic Reprogramming in Cancers under Normoxic Conditions. Cancers 2021, 13, 5557. https:/ / doi.org/10.3390/cancers13215557

Academic Editor: Masaru Katoh

Received: 5 October 2021

Accepted: 4 November 2021

Published: 5 November 2021

Publisher's Note: MDPI stays neutral with regard to jurisdictional claims in published maps and institutional affiliations.

Copyright: (c) 2021 by the authors. Licensee MDPI, Basel, Switzerland. This article is an open access article distributed under the terms and conditions of the Creative Commons Attribution (CC BY) license (https:// creativecommons.org/licenses/by/ $4.0 /)$.
Simple Summary: The canonical WNT/ $\beta$-catenin pathway is upregulated in cancers and plays a major role in proliferation, invasion, apoptosis and angiogenesis. Recent studies have shown that cancer processes are involved under normoxic conditions. These findings completely change the way of approaching the study of the cancer process. In this review, we focus on the fact that, under normoxic conditions, the overstimulation of the $\mathrm{WNT} / \beta$-catenin pathway leads to modifications in the tumor micro-environment and the activation of the Warburg effect, i.e., aerobic glycolysis, autophagy and glutaminolysis, which in turn participate in tumor growth.

Abstract: The canonical WNT/ $\beta$-catenin pathway is upregulated in cancers and plays a major role in proliferation, invasion, apoptosis and angiogenesis. Nuclear $\beta$-catenin accumulation is associated with cancer. Hypoxic mechanisms lead to the activation of the hypoxia-inducible factor (HIF)- $1 \alpha$, promoting glycolytic and energetic metabolism and angiogenesis. However, HIF- $1 \alpha$ is degraded by the HIF prolyl hydroxylase under normoxia, conditions under which the WNT/ $\beta$ catenin pathway can activate HIF-1 $\alpha$. This review is therefore focused on the interaction between the upregulated WNT/ $\beta$-catenin pathway and the metabolic processes underlying cancer mechanisms under normoxic conditions. The WNT pathway stimulates the PI3K/Akt pathway, the STAT3 pathway and the transduction of WNT/ $\beta$-catenin target genes (such as c-Myc) to activate HIF- $1 \alpha$ activity in a hypoxia-independent manner. In cancers, stimulation of the WNT/ $\beta$-catenin pathway induces many glycolytic enzymes, which in turn induce metabolic reprogramming, known as the Warburg effect or aerobic glycolysis, leading to lactate overproduction. The activation of the Wnt/ $\beta$ catenin pathway induces gene transactivation via WNT target genes, c-Myc and cyclin D1, or via HIF-1 $\alpha$. This in turn encodes aerobic glycolysis enzymes, including glucose transporter, hexokinase 2, pyruvate kinase M2, pyruvate dehydrogenase kinase 1 and lactate dehydrogenase- $\mathrm{A}$, leading to lactate production. The increase in lactate production is associated with modifications to the tumor microenvironment and tumor growth under normoxic conditions. Moreover, increased lactate production is associated with overexpression of VEGF, a key inducer of angiogenesis. Thus, under normoxic conditions, overstimulation of the WNT/ $\beta$-catenin pathway leads to modifications of the tumor microenvironment and activation of the Warburg effect, autophagy and glutaminolysis, which in turn participate in tumor growth.

Keywords: cancer; WNT/ $\beta$-catenin pathway; normoxia; Warburg effect; autophagy; lactate; aerobic glycolysis; HIF-1 $\alpha$; metabolic reprogramming; angiogenesis; VEGF; glutaminolysis 


\section{Introduction}

Metabolic reprogramming is one of the main characteristics of cancer cell activity. Cancer metabolism reprogramming not only provides ATP (adenosine triphosphate) for cancer cells, but also essential macromolecules for its protein and nucleotide biosynthesis. Several studies have shown that cancer cell metabolic reprogramming is controlled by a number of different factors [1,2], among which are the tumor microenvironment and hypoxia. Either an inflamed microenvironment, hypoxia or both, are in part responsible for the increase in glucose uptake and lactate production levels. In parallel, expressions of several key enzymes involved in the metabolic process are activated and lead to the same results.

Metabolic reprogramming in cancers is characterized by two processes involving autophagy and the Warburg glycolysis. Autophagy in cancers impairs mitochondrial energy homeostasis and favors inflammation and oxidative stress [3]. During tumor progression, the metabolic state of cells changes, involving both the glucose and lipid metabolism, biological oxidation and iron metabolism [4]. Metabolic reprogramming leads to several abnormalities in biochemical and biophysical functions. Cancer cells adopt a glycolysis modulation in the presence of sufficient oxygen, known as the Warburg effect or aerobic glycolysis [5]. The Warburg effect involves cell proliferation [6] and cell migration [7] but also drug resistance [8] and radioresistance [9]. The autophagy modulation and conversion of metabolism to aerobic glycolysis is a key feature of the cancer process and is associated with an aggressive clinical behavior [10].

The canonical WNT/ $\beta$-catenin pathway modulates several signaling processes involved in tissue homeostasis. It is now well established that activation of the canonical $\mathrm{WNT} / \beta$-catenin pathway is necessary for cancer cell survival and maintenance, making it a promising target for an anticancer therapy regimen [11]. An aberrant WNT/ $\beta$-catenin pathway has been observed in numerous cancers [12-16] resulting in the stimulation of numerous WNT target genes involved in tumor initiation, progression and aggressiveness. These genes include c-Myc, cyclin D1, the hypoxia inducible factor- $1 \alpha(\mathrm{HIF}-1 \alpha)$ [17], the production of reactive oxygen species (ROSs) [18] and the activation of chronic inflammation [19].

In recent years, many studies have observed the increase in $\mathrm{WNT} / \beta$-catenin signaling under normoxic conditions, leading to the enhancement of different pathways involved in the processes of cancer progression $[2,20]$. Thus, studies have shown the significant role of this pathway in the initiation of angiogenesis under normoxic conditions, its implication in autophagy modulation and the enhancement of the Warburg effect [17]. Nevertheless, the details of the regulatory process of metabolic reprogramming under normoxic conditions in cancer cells remain somewhat unclear. To address this point, the present review focuses on the interactions between the upregulated WNT/ $\beta$-catenin pathway and the metabolic mechanisms underlying the cancer process under normoxic conditions.

\section{Metabolic Reprogramming in Cancers: The Warburg Effect}

For decades, the Warburg effect (also known as aerobic glycolysis) has been described as the sequelae of damaged mitochondria [21] and as a metabolic signature of cancer cells. At the same time, oxygen absorption rates for most cancers are determined by the availability of $\mathrm{O}_{2}$, which is the blood concentration of $\mathrm{O}_{2}$ multiplied by blood flow [22,23]. $\mathrm{O}_{2}$ absorption rates depend on the availability of $\mathrm{O} 2$ and therefore on the effectiveness of blood flow [24]. An increase in blood flow in individual tumors during hyperthermia is followed by an increase in $\mathrm{O}_{2}$ absorption levels [25]. Isolated tumor cells exponentially stimulate their $\mathrm{O}_{2}$ consumption levels as the temperature rises to a maximum of around $42{ }^{\circ} \mathrm{C}$. The temperature coefficient $\mathrm{Q} 10$ obtained (also called the van ' $t$ Hoff coefficient) is 2.3, thus clearly showing fully functional mitochondrion [25]. The concentration of $\mathrm{O}_{2}$ in the arterial blood feeding a tumor is a function of either the partial $\mathrm{O}_{2}$ arterial pressure $\left(\mathrm{pO}_{2}\right)$, the hemoglobin content $(\mathrm{cHb})$ or in combination. Modifications to each of these 
parameters influence the availability of oxygen as well as the rate of $\mathrm{O} 2$ absorption by tumors [25].

The Warburg effect still attracts considerable interest in research based on mutations in TCA (tricarboxylic acid) cycle enzymes [26] and the increase in ROSs in tumor cells due to a decline in the ROS-scavenging enzyme, superoxide dismutase-II (SOD-II), in mitochondria [27].

The aerobic glycolysis may not simply be due to an increase in the glycolytic mechanism, but also to a decrease in the activity of mitochondria. This phenomenon is stimulated by the transcription factor HIF- $1 \alpha$, which can be increased under both hypoxic and normoxic conditions. HIF is considered to be a major modulator of the Warburg effect. HIF- $1 \alpha$ can decrease the mitochondrial mechanism by direct stimulation of pyruvate dehydrogenase kinase 1 (PDK-1), which in turn inhibits the PDH (pyruvate dehydrogenase). Pyruvate (the final product of glycolysis) cannot enter the TCA cycle, which results in a reduction in OXPHOS (oxidative phosphorylation), cellular oxygen consumption and ROS generation $[17,28]$. A second mechanism induced by HIF-1 is the decrease in the proportion of mitochondria per cell, due to the involvement of MXI1, a c-Myc antagonist, which controls the biogenesis of mitochondria. A third process, by which HIF-1 modulates the mitochondrial role, is the modification of the activity of cytochrome oxidase [28].

\subsection{Warburg Effect, a Major Feature of Metabolic Reprogramming}

Metabolic reprogramming, a consequence of metabolism plasticity, has been observed as one of the major mechanisms in cancer processes [29]. This process is characterized by the dysregulation of the glycolytic and glutaminolytic pathways. The increase of glycolytic flow is achieved by the stimulation of the phosphatidylinositol-3-kinase/protein kinase $\mathrm{B}$ (PI3K/Akt) pathway and HIF-1 $\alpha$ [20] or by other processes, such as the production of reactive oxygen species (ROSs), mutations of tumor suppressors (PTEN, p53, VHL) or oncogene activation (c-Myc, Ras, Raf). The increase of glycolytic flow can also be achieved through decreased AMPK signaling (AMP-activated protein kinase), as well as by the activation of c-Myc which stimulates glucose transporters GLUT-1 and GLUT-3 and phosphofructokinase (PFK) [30,31]. All of these alterations are implemented in the hostile tumor microenvironment (TME) under normoxic conditions, contributing to the development of the aerobic glycolysis phenotype.

In parallel with the limited supply of ATP, the Warburg effect produces antioxidant fragments (2 NADH per glucose mole) and enables the diversion of glycolytic intermediates to numerous biosynthesis pathways (NADPH, lipids and non-essential amino acids), thus supporting biosynthesis pathways as long as adequate glucose intake is controlled. These biosynthesis pathways are caused by a decrease in the role of the pyruvate kinase enzyme, which catalyzes the final stage of the Warburg effect, converting phosphoenolpyruvate into pyruvate. Aerobic glycolysis can decrease the production of ROSs [32] which, at low concentrations, can improve cancer cell survival rates [33] as long as glucose intake is maintained at the required level [34]. High glycolytic levels may involve a depletion of glucose in the TME to below physiological rates [34].

\subsection{Warburg Effect: Release of Lactate, a Fuel for Normoxic Cancer Cells}

High rates of lactate release in TME result from increased regulation of aerobic glycolysis, and c-Myc-induced glutaminolysis, another major feature of cancer metabolic reprogramming. For increased lactate production in the Warburg effect, activation of both HIF- $1 \alpha$ - and c-Myc increases the expression of PDK- 1 and lactate dehydrogenase A (LDHA), which converts pyruvate into lactate, contributing to the Warburg effect phenotype [35]. The increase in HIF-directed expression of PDK-1 inhibits PDH and therefore decreases the entry of pyruvate into the mitochondrial matrix and the Krebs cycle. 


\subsection{Lactates: A Fuel for Cancer Cells to Initiate Angiogenesis}

The transformation of the TME occurs in order to initiate angiogenesis. To increase molecular mechanisms and cellular movements, the cellular environment is modified. High lactate release rates lead to numerous cancerous mechanisms, including microenvironment transformation [36], cellular motility [37,38], impaired immune system [39,40] and antiapoptotic factors [41]. Lactate stimulation causes an increase in the nuclear factor-kappa B (NF-kB) pathway, which stops cell death by anti-apoptotic molecules, and initiates better cell survival in a hostile environment [42]. At the same time, lactate causes the transformation of the microenvironment, which directly activates angiogenesis [36,37,42-49].

The activation of glycolysis alters cellular $\mathrm{pH}$ and osmolarity by stimulating lactate production [50,51]. The TME has an acid $\mathrm{pH}$ [52]. In tumors, the vascular endothelial growth factor (VEGF) expression is stimulated by an acid microenvironment [53]. In cancer xenografts, a low $\mathrm{pH}$ level is independent of hypoxia [54]. Both acid $\mathrm{pH}$ and high lactate levels activate endothelial cells to generate VEGF and fibroblast growth factor- $\beta$ (FGF- $\beta$ ) $[42,44]$. Overproduction of lactate causes macrophages to generate VEGFA, which activates the initiation of both lymphatics and blood vessels [55-58]. VEGFA plays a key role with respect to vascular endothelial cells due to its associations with both VEGFR1 and VEGFR2. VEGFA activates the mitogenesis of endothelial cells and induces cellular migration. VEGF and FGF- $\beta$ stimulate the proliferation and motility of endothelial cells and the budding of the vascular system $[55,56,58]$. An increase in lactate rates due to glycolysis stimulates HIF- $1 \alpha$ in a positive feedback under normoxic conditions [57].

Lactate acid stimulates the production of metalloproteases and plasmin, disrupting the ECM, collagen and basal membrane $[36,37,55]$. Stored growth factors, including FGF- $\beta$, VEGFA and TGF- $\beta$, are released from the ECM $[36,37,44,55]$. TGF- $\beta$ is a major controller of cancer cell migration $[37,38]$.

Lactate activates the production of vascular growth factors by tumor cells, macrophages and fibroblasts [59]. Lactate activates the role of HIF- $1 \alpha$ under normoxic conditions through several processes, regardless of the oxygen level [60-63]. Lactate stimulates the HIF-1 $\alpha$ through the von Hippel-Lindau protein, a major protein for the destruction of HIF- $1 \alpha$. Lactate alters the role of the prolyl hydroxylase, which degrades HIF [44].

Numerous genetic mutations (including mutated genes that encode the colony stimulating factor (CSF) receptor), the epidermal growth factor receptor (EGFR), p53 and PTEN (phosphatase and TENsin homolog), result in HIF-1 $\alpha$ stabilization and stimulate angiogenesis through the upward control of angiogenic factors [64-68]. Stimulation of HIF-1 $\alpha$ increases the transcription of target genes, such as glucose transporters, monocarboxylate transporter-4 (MCT-4) and key proangiogenic effectors, such as VEGF [20,69]. HIF-1 $\alpha$ also initiates both the glycolytic energy metabolism and angiogenesis and contributes to poor tumor prognosis [70,71]. Lactate causes excess collagen deposition [57,72] and plays a major role in angiogenesis through VEGF stimulation [73-75]. HIF- $1 \alpha$ and lactate anion positively control the expression of MCT [76,77]. Lactate penetrates the tumor endothelial cells and the release of lactate by tumor cells via MCT- 4 is sufficient to activate the process of angiogenesis [42]. In cancers, lactate also causes stimulation of HIF- $1 \alpha$ independently of hypoxia by inhibiting the hydroxylation of the proline of HIF-1 $\alpha$ [61]. Lactate overproduction in endothelial cells activates HIF- $1 \alpha$ in a positive feedback loop in normoxia, resulting in the activation of proangiogenic genes, such as VEGFR2 [78]. VEGFR2 is a major modulator of the proangiogenic actions of VEGF [79]. Aerobic glycolysis-induced lactate stimulates the VEGF/VEGFR2 pathway in a manner independent of hypoxia [80]. Tumor cells surrounding the stroma have a high level of hyaluronan, which stimulates tumor growth and motility of tumor cells [81,82]. Hyaluronan refers to hyaluronic acid (HA) or hyaluronate and is a natural non-sulphate glycosaminoglycan (GAG) component found in the ECM of epithelial and neural tissues [83]. Hyaluronan has an important function in the development of embryonic tissues [84] and works to maintain the tissue homeostasis. Lactate stimulates the production of hyaluronan, which activates the angiogenic process $[85,86]$. Hyaluronan binds with membrane receptors, stimulates mitogenic genes 
and generates amoeboid movement [37]. HA oligomers are produced as HA degradation products by hyaluronidase (HYAl-1) [87]. High levels of lactate activate hyaluronidases to cause AH to be degraded into smaller fragments "in the form of oligomers" [85]. HA oligomers compete with native long-chain $\mathrm{AH}$ to bind with the HA CD44 receptor found in endothelial cells. HA oligomers stimulate the proliferation of endothelial cells [88] and initiate angiogenesis [89]. CD44-HA oligosaccharide interactions activate the production of matrix metalloproteinase-2 and-9 (MMP-2 and MMP-9), induce cell invasion, via ECM barriers, and generate vessel germination and growth [90,91].

\section{The Key Role of the WNT/ $\beta$-Catenin Pathway in Cancer Development under Normoxic Conditions}

The Canonical WNT/ $\beta$-Catenin Pathway

The WNT name is derived from Wingless Drosophila melanogaster and its mouse homolog Int. The WNT/ $\beta$-catenin pathway is involved in numerous signals and molecular pathways, including embryogenesis, cell proliferation, cell migration and cell polarity, apoptosis and organogenesis [92]. Nevertheless, the WNT/ $\beta$-catenin pathway can be deregulated during numerous pathological states, such as inflammation, neurological disorders, metabolic diseases, tissue fibrosis and cancer mechanisms [93].

The WNT pathway belongs to the family of secreted lipid-modified glycoproteins [94] (Figure 1). WNT ligands are mainly secreted by both neurons and immune cells located in the central nervous system (CNS) [95]. Modulation of the WNT/ $\beta$-catenin pathway involves metabolic pathways, embryonic development, cell fate and epithelial-mesenchymal transition (EMT). WNT pathway deregulation contributes to numerous neurodegenerative diseases (NDs) [96-99].

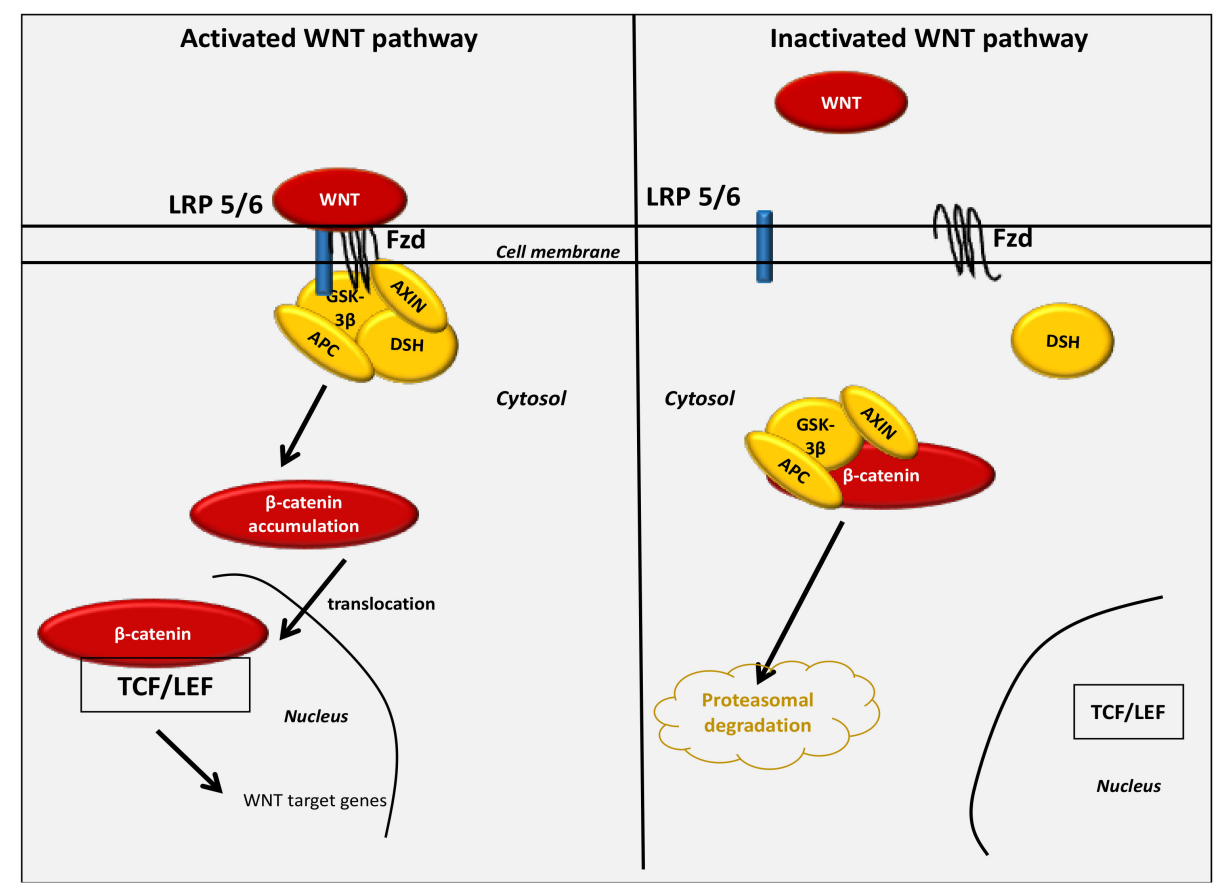

Figure 1. The activated and inactivated $\mathrm{WNT} / \beta$-catenin pathway.

At the transcriptional level, WNT signaling is primarily mediated by a family of transcription factors known as the $\beta$-catenin/T-cell factor/lymphoid enhancer factors (TCF/LEF). The accumulation in the cytoplasm of $\beta$-catenin is generated by the destruction complex AXIN, tumor suppressor adenomatous polyposis coli (APC) and glycogen synthase kinase-3 (GSK-3 $\beta$ ). In the absence of WNT ligands, the destruction complex enhances phosphorylation of the cytoplasmic $\beta$-catenin and induces its degradation in the proteasome. In the presence of the WNT ligands, $\beta$-catenin binds to Frizzled (FZL) and LDL receptor-related protein 5/6 (LRP 5/6) [100], thereby stopping the destruction complex 
and preventing the degradation of $\beta$-catenin in the proteasome. $\beta$-catenin translocates into the nucleus where it binds with the complex TCF/LEF. This in turn stimulates WNT targets [101-103].

GSK-3 $\beta$ is a major negative modulator of $W N T / \beta$-catenin signaling [104-109]. As an intracellular serine-threonine kinase, GSK-3 $\beta$ is a negative controller of the WNT pathway [110]. It is involved in the modulation of numerous kinds of pathophysiological signaling, such as the cell membrane pathway, cell polarity and inflammatory processes [111-113]. GSK-3 $\beta$ downregulates cytosolic $\beta$-catenin and stabilizes it, leading to the interruption of the nuclear migration of $\beta$-catenin. Inflammation is an age-related mechanism correlated with the stimulation of GSK-3 $\beta$ activity and a decrease in WNT/ $\beta$-catenin pathway activity [114].

\section{The WNT/ $\beta$-Catenin Pathway Stimulates Cancer Metabolic Reprogramming under Normoxic Conditions}

\subsection{Interactions between the Canonical WNT/B-Catenin Pathway and the Warburg Effect}

Glucose is the main source of energy for cells. Glucose is metabolized to generate ATP (as energy) by cytoplasmic glycolytic mechanisms and oxygen-dependent mitochondrial processes (Figure 2).

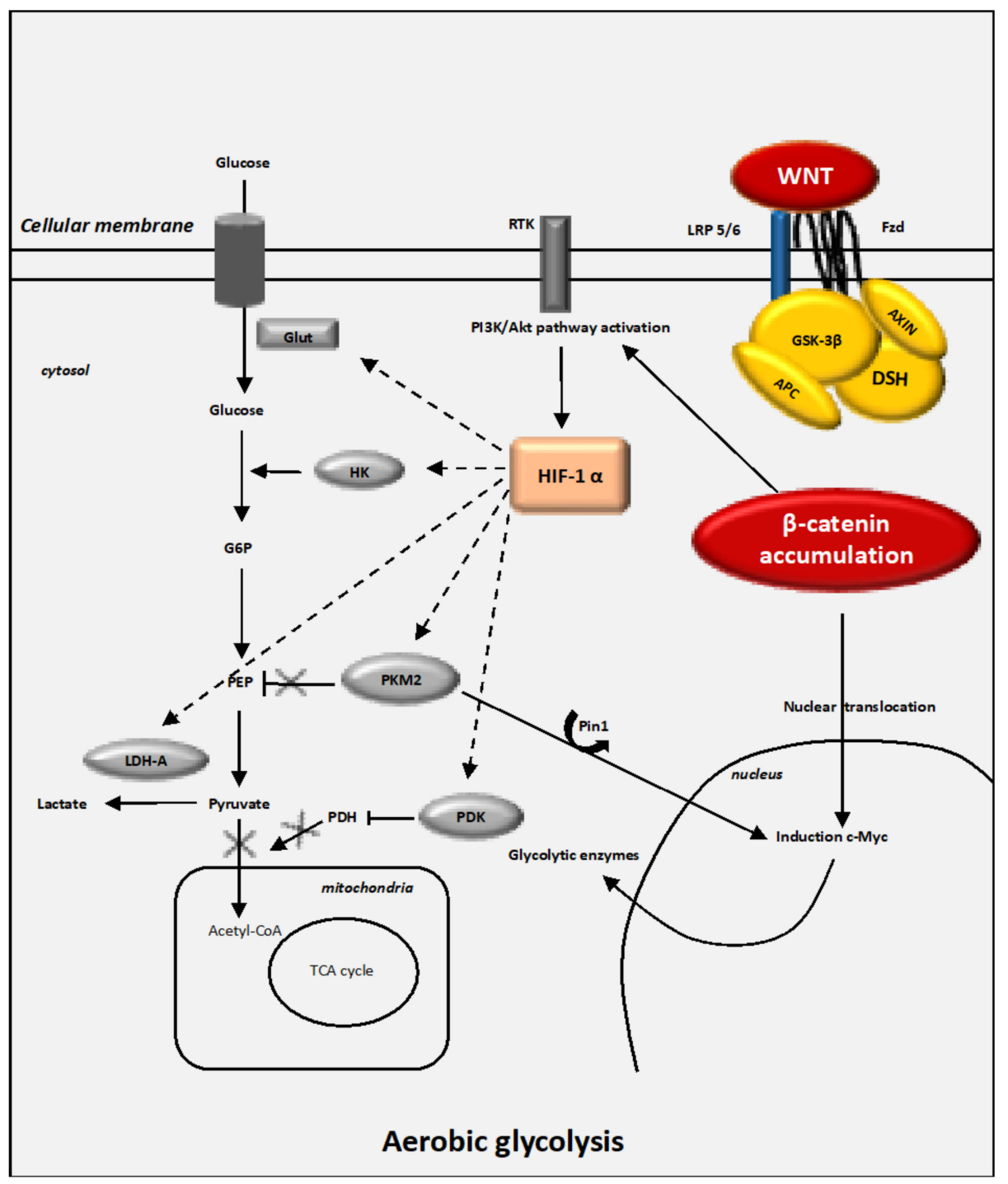

Figure 2. The WNT/ $\beta$-catenin pathway and the Warburg effect. WNT ligands bind with the Frizzled/LRP 5/ 6 receptor complex, leading to LRP phosphorylation of the AXIN/APC/GSK-3 $\beta$ 
complex. $\beta$-catenin accumulates in the cytoplasm to translocate to the nucleus. The WNT-process transcription activity is then stimulated. MCT-1 enhances lactate release out of the cell. The stimulation of the PI3K/Akt pathway is associated with the activation of the glucose process. Increased levels of aerobic glycolysis are associated with higher lactate production and a decrease in mitochondrial respiration. HIF-1 $\alpha$ activation leads to the cytoplasmic pyruvate being shunted into lactate by MDH-A induction. The pyruvate cannot then be fully converted into acetyl-CoA and enter the TCA cycle. The entry of glucose into the TCA cycle is modulated by the pyruvate dehydrogenase complex (PDH). A decrease in PDH inhibits the activity of the mitochondria in several cancers [115]. In tumor cells, the activation of the WNT/ $\beta$-catenin pathway enhances aerobic glycolysis [116]. PDK- 1 is activated in vitro and in living colon tumor cells [117] and there is a decrease in the conversion of pyruvate into acetyl-CoA in mitochondria [118]. PDK-1, LDH-A and MCT-1 are stimulated in cancer cells [57,119]. c-Myc and cyclin D1 also stimulate aerobic glycolysis [120]. The activation of c-Myc and PI3K/Akt signaling leads to the stimulation of HIF-1 $\alpha$ activity, which inhibits glucose entry into the TCA cycle [121,122]. The stimulation of HIF-1 $\alpha$ increases the expression of Glut, HK, PK, PDK-1 and LDH-A [20,123,124]. Glut allows the entry of glucose into the cytoplasm where glycolysis ensues. HK phosphorylates glucose during the first stage of glycolysis. PK controls the production of pyruvate during the last stage of glycolysis. PDH stimulates the entry of pyruvate into the oxidative phosphorylation process and thus the tricarboxylic acid (TCA) cycle within the mitochondria. Activation of HIF-1 $\alpha$ stimulates PDK-1, inactivating PDH. The stimulation of LDH-A leads to the conversion of pyruvate into lactate. Abbreviations: GSK: glycogen synthase kinase, DSH: disheveled, APC: adenomatous polyposis coli, HIF: hypoxic inducible factor, RTK: tyrosine kinase receptor, Glut: glucose transporter, HK: hexokinase, PKM2: pyruvate kinase M2, LDH: lactate dehydrogenase, PDK: pyruvate dehydrogenase kinase, TCA: tricarboxylic cycle.

Tumor cells are dependent on glycolysis for their primary source of energy [125], with activation of the glycolytic metabolism [126]. Instead of primarily using oxidative phosphorylation (OXPHOS), cancer cells use less efficient glycolysis for ATP production. However, some cancers have the ability to produce ATP in an OXPHOS-dependent manner, such as cancer stem cells [127]. Activation of the intracellular concentration of lactate in tumor cells is associated with a progressive decrease in TCA cycle activity [128].

\subsection{Interactions between the WNT/B-Catenin Pathway and STAT3 Pathway}

The STAT3 (signal transducer and activators of transcription 3) belongs to the family of cytosolic transcription factors that allow the activation of nuclear pathways [129]. The STAT3 pathway plays an important role in cell mechanisms, including differentiation, proliferation, apoptosis and angiogenesis [130]. A stimulated STAT3 pathway is observed in several cancers [131]. The STAT3 pathway induces tumorigenesis by the stimulation of genes encoding cell-cycle regulators (cyclin D1, c-Myc) and also stimulates VEGF activity [132].

A STAT3 phosphorylated by IL-6 or LIF (leukemia inhibitory factor) is associated with activation of HIF-1 $\alpha$ in normoxia [133]. The $\beta$-catenin/TCF4 complex directly interacts with STAT3 signaling [134]. STAT3 is essential for mesenchymal transformation and tumor aggressiveness [135] and is considered as a downstream pathway of mTOR signaling [136]. STAT3 and its downstream Notch receptor operate in several cellular and molecular mechanisms such as proliferation, differentiation and apoptosis [137]. The decrease in STAT3 activity inhibits cancer cell growth, invasion, migration, cell-cycle progression and differentiation [138] (Figure 3).

\subsection{Interaction between the WNT/ $\beta$-Catenin Pathway and the PI3K/Akt Pathway}

The receptor tyrosine kinase (RTK) and the EGFR are enhanced in cell division, migration, adhesion, differentiation and apoptosis [139,140]. EGFR interacts with the PI3K/Akt/STAT pathways to control proliferation, differentiation and cell survival [141, 142]. PI3K is directly stimulated by EGFR. PI3K converts PIP2 into PIP3 [143,144]. The role 
of PI3K is inhibited by PTEN, which converts PIP3 back to PIP2 [145]. PI3K stimulates the Akt pathway by phosphorylating it [146]. The activated Akt pathway decreases the activity of GSK-3 $\beta$ and allows the nuclear translocation of $\beta$-catenin [143]. The PI3K/Akt pathway controls $\beta$-catenin stability, nuclear translocation, transcriptional activity and the expression of its downstream genes, including Cyclin D1 and c-Myc [144].

The PI3K/Akt pathway plays a key role in the control of cellular metabolism, growth, proliferation and cell survival $[147,148]$. The WNT / $\beta$-catenin pathway directly activates RTK in tumor cells [149] (Figure 3). Decreased $\beta$-catenin leads to a reduction in EGFR expression as well as in the Akt pathway and its downstream genes [150]. The WNT/ $\beta$ catenin pathway and the PI3K/ Akt pathway control each other in a positive feedback loop. PI3K produces PIP3, binding with PDK-1 through a pleckstrin homology domain (PH). The activation of PDK-1 phosphorylates and then stimulates the Akt pathway [151]. The mechanistic target of rapamycin (mTOR) is one of the main markers of tumor growth. The kinase mTOR acts through two different proteins, i.e., mTORC1 and mTORC2, which are distinct with respect to the composition of their subunits, upstream inputs, downstream substrates and their roles [148,152].

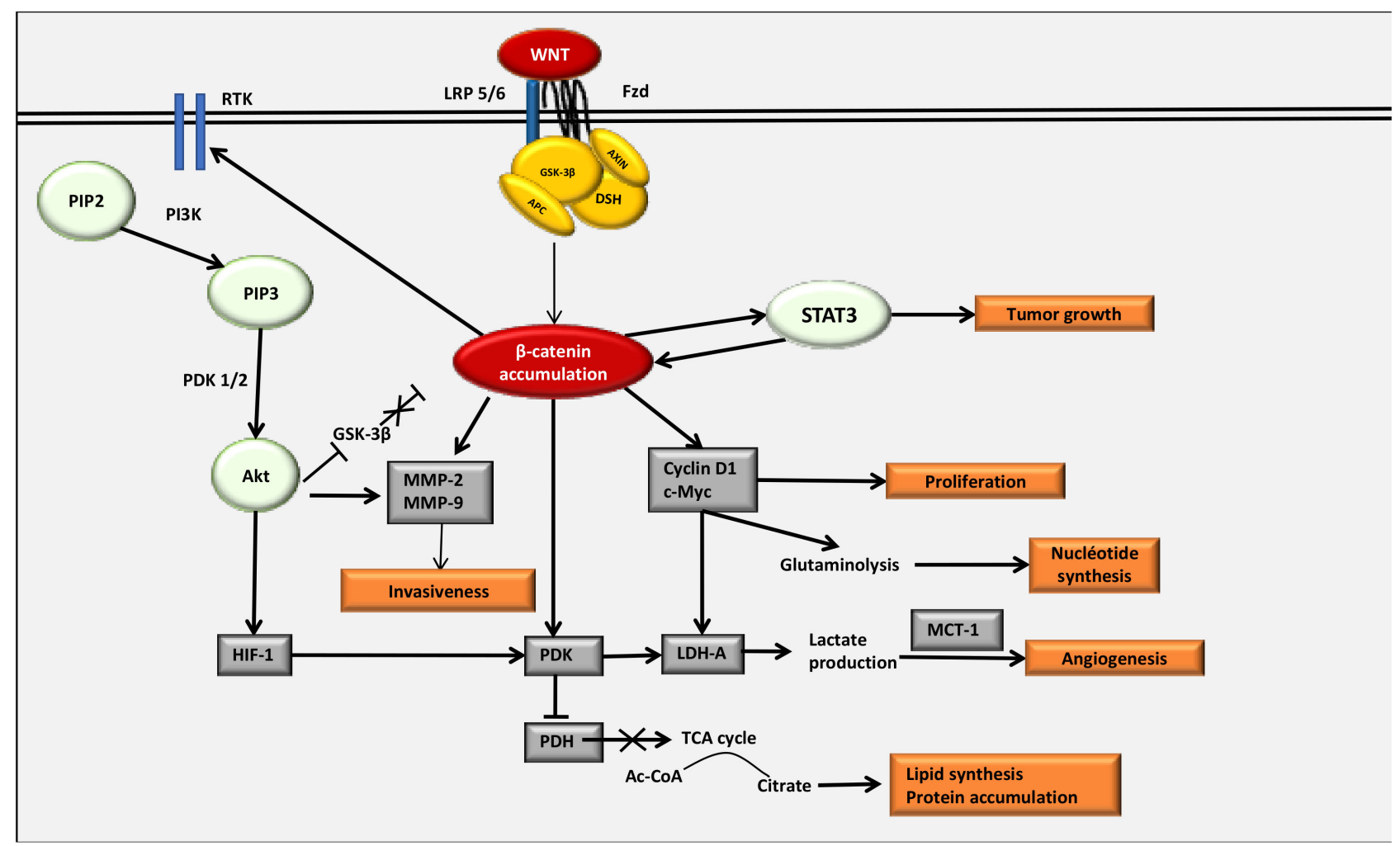

Figure 3. The WNT/ $\beta$-catenin pathway and its different actions in cancer processes. The WNT plays a major role in cancer processes by interacting with the STAT3 pathway, leading to tumor growth, by stimulating cyclin D1 and c-Myc, responsible for cell proliferation and then for the glutaminolysis mechanism responsible for the nucleotide synthesis. $\beta$-catenin directly activates RTK, which in turn stimulates the PI3K/Akt pathway leading to the inactivation of the GSK-3 $\beta$, a major inhibitor of $\beta$-catenin. Activated Akt stimulates MMP-2 and MMP-9, which are responsible for the invasiveness. The double action of $\beta$-catenin and the PI3K/Akt pathway for the activation of the HIF- $1 \alpha$ enhances the stimulation of the PDK, which in turn inactivates the PDH and stops the TCA cycle. The TCA cycle arrest leads to lipid synthesis and protein accumulation in cancers. Moreover, LDH-1 is directly responsible for the production of lactate and its translocation over the cell by MCT-1, which in turn stimulates angiogenesis. Abbreviations: GSK: glycogen synthase kinase, HIF: hypoxic inducible factor, RTK: tyrosine kinase receptor, LDH: lactate dehydrogenase, PDK: pyruvate dehydrogenase kinase, TCA: tricarboxylic cycle, MCT: monocarboxylate transporter. 
PI3K activates mTORC1 through a dependent Akt pathway. mTORC1 decreases the tuberous sclerosis complex (TSC) [153,154]. TSC phosphorylation decreases its GTPaseactivating protein (GAP) activity for the small GTPase Ras homolog enriched in brain (Rheb). This phenomenon leads to a decrease in Rheb and the activation of mTORC1 $[155,156]$. Rheb is a major positive marker of mTORC1 [157-159] through direct binding with mLST8, the kinase domain of mTOR, $[157,160]$. By a mTORC1 negative loop, Rheb can downregulate PI3K and mTORC2 pathways [161]. mTORC2 can also stimulate the Akt pathway [162]. Nevertheless, mTORC2 activity is enhanced in a PI3K-dependent manner [163]. The PI3K/Akt pathway can stimulate mTORC2 activity by activating IKK $\alpha$ [164]. Stimulation of PI3K/Akt signaling is associated with the activation of mTORC1 [165], following its dissociation from PRAS40.

\subsection{The Key Enzymes Involved in Metabolic Reprogramming in Cancer Cells 4.4.1. HIF- $1 \alpha$}

HIF- $1 \alpha$ expression in human bodies enhances angiogenesis by transcriptionally stimulating several angiogenic genes and their receptors, including VEGF [166]. HIF-1 is a heterodimeric nuclear transcription factor consisting of two compounds: HIF- $1 \alpha$ and HIF$1 \beta$. The action of HIF- $1 \alpha$ is modulated by changes in local oxygen rates. Under normoxia, HIF- $1 \alpha$ is destroyed by HIF prolyl hydroxylases $[167,168]$.

Activation of HIF- $1 \alpha$ leads to the activation of gene transcription encoding several glycolysis enzymes (i.e., LDH-A, PKM2 and PDK-1) [169-171] (Figures 2 and 3). HIF-1 $\alpha$ is stimulated in several oncogenic processes even under normoxic conditions $[57,58,172,173]$. The transcriptional activity of HIF- $1 \alpha$ is stimulated by mTOR even under normoxia by 4E-BP1 and STAT3 [133,174-178]. mTOR-mediated HIF-1 $\alpha$ induction can mimic the action of hypoxia, leading to the glycolysis mechanism [123].

\subsubsection{Glut-1 and HK2}

Glucose-transporters, Glut-1 and Glut-3, have their main roles in the insulin-sensitive homeostasis of glucose transport [179]. Glut-1 expression is stimulated in cancer processes [180]. HIF-1 $\alpha$ stimulates the glycolytic flux by activating the glucose uptake and its metabolism by directly activating both Glut- 1 and Hexokinase 2 (HK2) $[118,181,182]$ (Figure 3). HIF-1 $\alpha$ stimulates the expression of Glut-1 to increase the intracellular glucose levels, which favor glycolysis and tumor development [183-185].

HK2 activation leads to the transformation of glucose into glucose-6-phosphate. HK2 is stimulated by both c-Myc and HIF-1 $\alpha[121,124,186]$. High rates of HK2 lead to the development of cancers [187]. However, the downregulation of HK2 activity in cancers could prevent the aerobic glycolysis mechanism, leading to a reduction in tumor growth [188].

\subsubsection{PKM2}

The final step of glucose metabolism is the conversion of phosphoenolpyruvate and adenosine diphosphate (ADP) into both ATP and pyruvate. The enzyme pyruvate kinase (PK) is responsible for this phenomenon. Four isozymes of PK are defined: PKL, PKR, PKM1 and PKM2 [189]. PKM2 is overstimulated in cancers [190,191]. Under high glucose levels, PKM2 enters into the nucleus through the activity of peptidyl-prolyl isomerase 1 (Pin1) [192] (Figure 3). Pin1 is stimulated in cancer processes to inactivate tumor growth inhibitors $[193,194]$. Pin1 is directly stimulated by EGFR to generate the nuclear translocation of PKM2 [195]. Under normoxic conditions, mTOR activates PKM2 activity by stimulating HIF-1 $\alpha$ [123]. Thus, nuclear PKM2 can target $\beta$-catenin leading to c-Myc-mediated expression of glycolytic enzymes [195].

\subsubsection{PDK-1}

PDK-1 acts as a major modulator of the glycolysis metabolism by directly phosphorylating the $\mathrm{PDH}$ complex to downregulate the mitochondrial conversion of pyruvate to acetyl-CoA [196]. PDK-1 controls the activity of PDH by phosphorylating three ser- 
ine residues in the $\alpha$ subunit of PDH-E1 [196], resulting in the inhibition of its activity (Figure 3). The stimulation of PDK is associated with the shunt of pyruvate away from the mitochondria to downregulate the flux through the TCA cycle. This action inhibits the release of NADH from the electron transport chain [115]. HIF- $1 \alpha$ directly stimulates the activity of PDK-1 to inhibit the conversion of pyruvate into acetyl-CoA [115].

\subsubsection{LDH-A}

LDH is a tetrameric enzyme that belongs to the 2-hydroxy acid oxidoreductase family. $\mathrm{LDH}$ stimulates the levels of both the inter-conversion of pyruvate to lactate and the nicotinamide adenine dinucleotide (NADH) into NAD+ [197]. Four LDH subunits are defined: LDH-A, LDH-B, LDH-C and LDH-D. LDH-A is the main enantiomer observed in vertebrates. LDH-A plays a number of major roles in cancer cells, including gene transcription, angiogenesis, tumor migration and tumor evasion of immune response [37,38,198-200]. In cancer cells, the stimulation of LDH-A activates the lactate production [201]. LDH-A is mainly stimulated by both HIF-1 $\alpha$ and c-Myc [202-205] (Figure 3). Under normoxic conditions and in a positive interplay, LDH-A can stimulate HIF- $1 \alpha$ expression to enhance lactate production $[61,206]$. Under normoxic conditions, LDH-A is also stimulated by c-Myc to promote HIF- $1 \alpha$ stabilization [200]. Moreover, the stimulation of LDH-A leads to the enhancement of VEGF $[207,208]$.

Independently of hypoxia, acidic extracellular $\mathrm{pH}$, caused by the increased lactate production, can upregulate IL-8 and VEGF [48,53,54,209-211]. In cancer cells, VEGF expression is modulated by $\mathrm{pH}$ and tissue $\mathrm{pO} 2$ [54]. Hypoxia and acidic $\mathrm{pH}$ present no synergistic actions on the transcription of VEGF [54].

\section{Definition of the Autophagy Mechanism}

It is widely known that autophagy is damaged in cancer processes. Autophagy represents a major mechanism in preserving stem cell homeostasis by finely tuning stem cell maintenance and differentiation [212,213]. In physiological cells, autophagy can act as a tumor-suppressive process through the maintenance of cell homeostasis, whereas in tumor cells, autophagy can exert either tumor-promoting or tumor-suppressing actions. It is still a subject of debate as to whether autophagy activation or diminution could provide the most promising approach for future cancer therapies [214].

Autophagy (from the Greek word for "self-eating") is a phenomenon that depends on energy, and one that is highly regulated and conserved. Autophagy is responsible for the sequestration and recycling of redundant or altered cell organelles, long-lived proteins and even pathogens [215]. A basal rate of autophagy plays a major role in many cell types, maintaining cell homeostasis under normal conditions. However, its alteration can appear during development and results from several types of stress, including nutrient deprivation, DNA damage, hypoxia and oxidative metabolism [215].

Three types of autophagy may be identified at the cellular level: micro-autophagy, macro-autophagy and chaperone-mediated autophagy (CMA) [216].

Micro-autophagy follows the direct invagination of the lysosomal membrane, which forms an autophagic body and causes the degradation of the sequestered part of the cytosol [216]. The CMA involves a related thermal shock and a complex of other chaperones that recognize cytosolic target proteins with a KFERQ pattern. The CMA acts with the membrane protein associated with type 2a lysosome (LAMP2A) and directly brings the cargo to the lysosomal membrane $[217,218]$. The main form of autophagic degradation, that of macro-autophagy, occurs through multi-level phenomena beginning with the engulfment of cytosolic components in a crescent-shaped double membrane structure called the phagophore $[219,220]$.

Autophagy can be investigated at various stages: induction and initiation of autophagy, nucleation of the phagophore, expansion of the phagophore, targeting of cargo, completion of autophagosomes and fusion with lysosomes, and degradation of content [215]. Autophagy can have a dual role. During stress, autophagy induces cytoprotec- 
tive effects that prolong cell survival, while over-stimulation of cell survival/ cytoprotective effects can be harmful to the cell and induces apoptosis [221]. Numerous studies have demonstrated the involvement of deregulated autophagy in various pathological processes, such as cancer [222], neurodegenerative diseases [223], liver diseases [224], aging [225] and viral infections [226].

\section{Autophagy in Cancer}

As a crucial compound of cell defense mechanisms, autophagy has an important role in the destruction mechanism of damaged organs, dysregulated proteins and metabolite recycling in order to maintain the stability of the internal environment [227]. In cancers, autophagy has a dual role in both the promotion and suppression of tumors. Basal autophagy is weak and almost considered as a process of cancer suppression in the early stages of carcinogenesis through inhibition of ROSs, DNA and tissue damage, inflammation and genome instability [228]. Thus, the lack of key genes in autophagy may be the cause of carcinogenesis processes. The deletion of ATG5 and ATG7 contributes to the development of benign liver adenomas from autophagy-deficient hepatocytes via mitochondrial swelling and oxidative stress [229]. The BECN1 (Beclin 1) gene linked to autophagy is essential in the formation of the phagophore. The loss of the Beclin 1 gene linked to autophagy may contribute to the development of spontaneous tumors and can lead to an increase in cell proliferation in different types of tumors [230,231]. Autophagy, as a cancer suppressor, is also associated with a replicative seizure [232,233]. Replicative crisis is the final barrier before tumor development, leading to mitotic delay, amplified telomere deprotection and cell death. Autophagy also contributes to the tumor suppression crisis. The loss of autophagy stimulates the continuous proliferation and accumulation of genomic instability, a process essential to the onset of cancer [234]. Autophagy is considered to be a tumor suppressor because the process leads to the elimination of the oncogenic proteins involved in oncogenesis. BCR-ABL1, an oncogene protein responsible for the progression of leukemia, is degraded by autophagy [235].

However, while autophagy slows down the tumor initiation process, other studies have suggested that decreased autophagy may contribute to the tumor initiation process. Genetic ablation of essential autophagy genes in genetically modified mouse models for tumors has revealed the major role of autophagy in promoting malignant tumors [236,237]. Autophagy also promotes angiogenesis, metastases and invasion during tumorigenesis. Autophagy stimulates VEGFA through the janus kinase-2/signal-transducer and activator transcription-3 (JAK2/STAT3) and plays a major role in angiogenesis [238]. In parallel, the triggered autophagy could activate the Hippo YAP/TAZ signaling and stimulate cell invasion and tumor migration [239].

\section{Interplay between Glycolysis and Autophagy in the Cancer Process}

During tumor growth, cancer cells use metabolic reprogramming to maintain growth, survival, proliferation and migration processes. To meet different metabolic needs, autophagy is modified. Currently, the relationship between autophagy and glycolytic metabolism is subject to extensive investigation. Glucose is the major source of nutrients for the production of cellular energy and a constant supply of glucose is required for the production of ATP. As a major biological mechanism, glycolysis is consubstantial with autophagy. Metabolic reprogramming induces cancer progression to regulate autophagy. Thus, glycolysis controls autophagy and participates fully in the survival of tumor cells.

When the glycolytic process is decreased, as in the context of aerobic glycolysis, autophagy is improved and becomes a driving force for oxidative phosphorylation to support the production of ATP [240]. Pyruvate supplementation prevents RSL3-induced cell death, indicating that the dysfunction of glycolysis can cause autophagic cell death in glioma cells [241]. Similarly, the stability of EGFR, mediated by aerobic glycolysis, is essential for tumor survival. The inhibition of ATP production leads to the activation of ROSmediated c-Jun N-terminal kinase (JNK) and thus to the degradation of EGFR via inhibited 
autophagy [242]. Aerobic glycolysis regulates autophagy and plays a major role in the chemo-resistance of cancers. HK2 confers cisplatin resistance in ovarian cancer cells by increasing ERK1/2 phosphorylation and autophagic activity. Stopping autophagy through the autophagy inhibitor 3-methyladenine (3-MA) sensitizes cisplatin-resistant ovarian cancer cells [243]. Several studies have shown that in the most glycolytic dependent cells, autophagy is usually triggered by the accumulation of adenosine monophosphate (AMP) (via increased AMP/ATP ratio) and the stimulation of AMPK [244]. Thus, metabolic reprogramming caused by aerobic glycolysis stimulates autophagy, also induced by OXPHOS, and thus stimulates intracellular ROSs [245]. However, the mechanism for controlling aerobic glycolysis on autophagy is still not well understood. One interesting avenue of research is to examine the role of glycolytic enzymes in the functioning of the WNT pathway and its targets.

\subsection{Key Role of the WNT/B-Catenin Pathway in Cancer Development through Interaction with Autophagy}

The interaction between autophagy and distinct signaling, such as that associated with the WNT / $\beta$-catenin, SHH and TGF- $\beta$ pathways, has a vital role in several cellular mechanisms [246] (Figure 4).

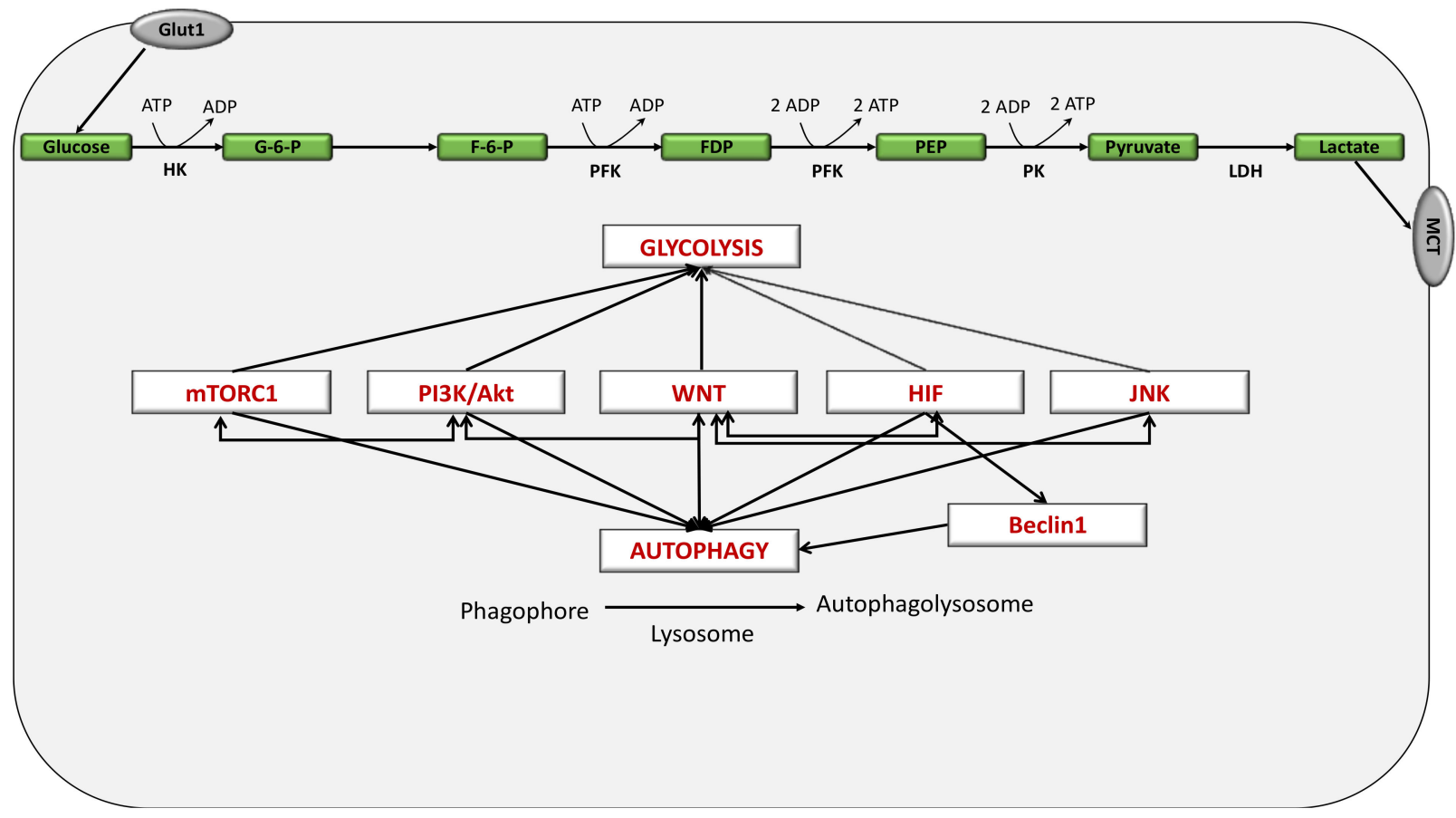

Figure 4. Interplay between the WNT/ $\beta$-catenin pathway, aerobic glycolysis and autophagy. The interactions between WNT, PI3K/Akt pathway, mTORC1, HIF and JNK result in stimulating both glycolysis and autophagy, involving several glycolytic enzymes (including, glucose, G6P, F6P, FDP, PEP, pyruvate producing lactate over the cell by MCT). Abbreviations: G-6-P: glucose 6 phosphate, F-6-P: fructose 6 phosphate, FDP: fructose diphosphate, PFK: phosphofructokinase, PEP: phosphoenolpyruvate, JNK: Jun N-terminal kinase, HIF: hypoxic inducible factor, mTORC1: mechanistic target of rapamycin $\mathrm{C} 1$.

Numerous studies have shown that activated WNT/ $\beta$-catenin is a negative controller of autophagy based on the evidence that high rates of autophagy are not compatible with cellular proliferation and survival enhanced by the WNT/ $\beta$-catenin pathway [247]. Activated WNT/ $\beta$-catenin diminishes the expression of Beclin 1, an inducer of autophagic flux [248]. Moreover, the activation of autophagy can decrease WNT/ $\beta$-catenin pathway activity through the degradation of DVL [249] and $\beta$-catenin [247]. Feedback processes between the WNT / $\beta$-catenin pathway and autophagy have been shown at distinct rates [215]. $\beta$-Catenin contains a LC3 interacting region (W/YXXI/L motif) that reveals a direct target 
of selective autophagy destruction via the LC3 binding site [215]. Moreover, activated autophagy leads to a decrease in WNT signaling through the autophagic degradation of $\beta$-catenin [247]. $\beta$-catenin can act as a gene repressor [250].

Thus, the WNT / $\beta$-catenin pathway exercises a negative control on autophagy. The nuclear accumulation of $\beta$-catenin leads to the inhibition of the p62/SQSTM1 promoter, which enhances autophagy diminution [250]. Conversely, the decrease in WNT/ $\beta$-catenin pathway activity leads to the stimulation of p62/SQSTM1 expression and to the nuclear accumulation of the TFEB transcription factor, inducing the autophagy process [251].

DVL is involved in the regulatory feedback process between autophagy and the WNT/ $\beta$-catenin pathway [252]. DVL is a selective target of destruction by a direct interaction with p62 and LC3. Under stress conditions, the von Hippel-Lindau protein (pVHL, an E3 ligase) triggers the ubiquitination of DVL, whereas hVHL is negatively regulated by GSK-3 $\beta$. p62 recognizes ubiquitinated DVL by its ubiquitin-associated domain and binds with LC3. DVL has an affinity with the LC3 interacting region (LIR). p62 binds with LC3 through LIR, which can directly target LC3, directing DVL degradation into the autophagosome [249]. Thus, the non-inhibition of GSK-3 $\beta$ activity by DVL leads to $\beta$-catenin phosphorylation, ubiquitination and then a diminution in $\mathrm{WNT} / \beta$-catenin pathway activity. DVL is phosphorylated by active ULK1 to become inactive [253]. Thus, following autophagy induction, DVL is inhibited and the WNT/ $\beta$-catenin pathway is attenuated $[254,255]$. GSK-3 $\beta$ is involved in mTOR signaling where tuberous sclerosis 2 (TSC2) is phosphorylated and stimulated by GSK-3 $\beta$ in association with AMPK [256]. Activation of TCS2 leads to mTOR diminution and thus to autophagy induction. The PI3K/Akt pathway catalyzes the phosphorylation of GSK-3 $\beta$ [257]. During autophagy induction, a positive feedback process is stimulated where DVL (a GSK-3 $\beta$ inhibitor) is damaged by LC3 interaction and derepressed GSK-3 $\beta$, leading to autophagy by TSC 2 phosphorylation [258]. GSK-3 $\beta$ represses the WNT/ $\beta$-catenin pathway and induces autophagy by phosphorylating TCS2. However, stimulated TSC2 decreases mTORC1, enhancing $\beta$ catenin stabilization [215]. The interplay between DVL-PI3K/ -WNT/ $\beta$-catenin pathway and the development of autophagy could provide the basis for cancer initiation [259].

Conversely, in vitro studies have shown that the WNT/ $\beta$-catenin pathway and autophagy can be stimulated at the same moment [260]. Thus the WNT/ $\beta$-catenin pathway was found to be involved in autophagy-induced glycolysis in hepatocarcinomatous cell lines [261]. Moreover, the WNT3a ligand activates autophagy in squamous cell carcinoma of the head and neck, sensitizing cells to radiotherapy [262].

\subsection{The Key Role of the WNT/ $\beta$-Catenin Pathway in Cancer Development through Interaction with Glutaminolysis}

In parallel to the shift toward the Warburg effect, tumor cells rely on the provision of bulk quantities of amino acids as major enhancers for cellular survival and growth, in order to complete the TCA cycle [263]. Stimulation of the glutamine uptake is wellknown in different cancers, such as breast cancer [264,265]. Nevertheless, glutaminolysis should be cancer-subtype-dependent. Triple-negative breast cancers are mainly dependent on glutamine so that therapies using glutamine-targeting drugs could provide the most effective treatment [266]. Glutamine has a major role in cell proliferation, survival and migration $[120,267]$. It undergoes glutaminolysis, a mechanism by which it is converted to glutamate and $\alpha$-ketoglutarate to replenish the TCA cycle, enhance protein synthesis and generate GSH. $\alpha$-Ketoglutarate can supplement the Warburg effect as it can be converted to malate and then to pyruvate [268]. Glutaminolysis is an energy pathway that is used by tumor cells to supply nitrogen to sustain their rapid division and energy requirements [269].

The WNT/ $\beta$-catenin pathway plays an important role in glutamine metabolism. Research has shown that $\beta$-catenin target genes are involved in glutamine uptake and metabolism [270]. While the exact process by which $W N T / \beta$-catenin interacts with glutaminolysis is still unclear, c-Myc could play a key role [271] (Figure 5). 
Although it has been suggested that the NF- $\mathrm{KB}$ pathway is a modulator of glutaminolysis in breast tumor cells, the role of the WNT/ $\beta$-catenin pathway in this control is still unclear [267].

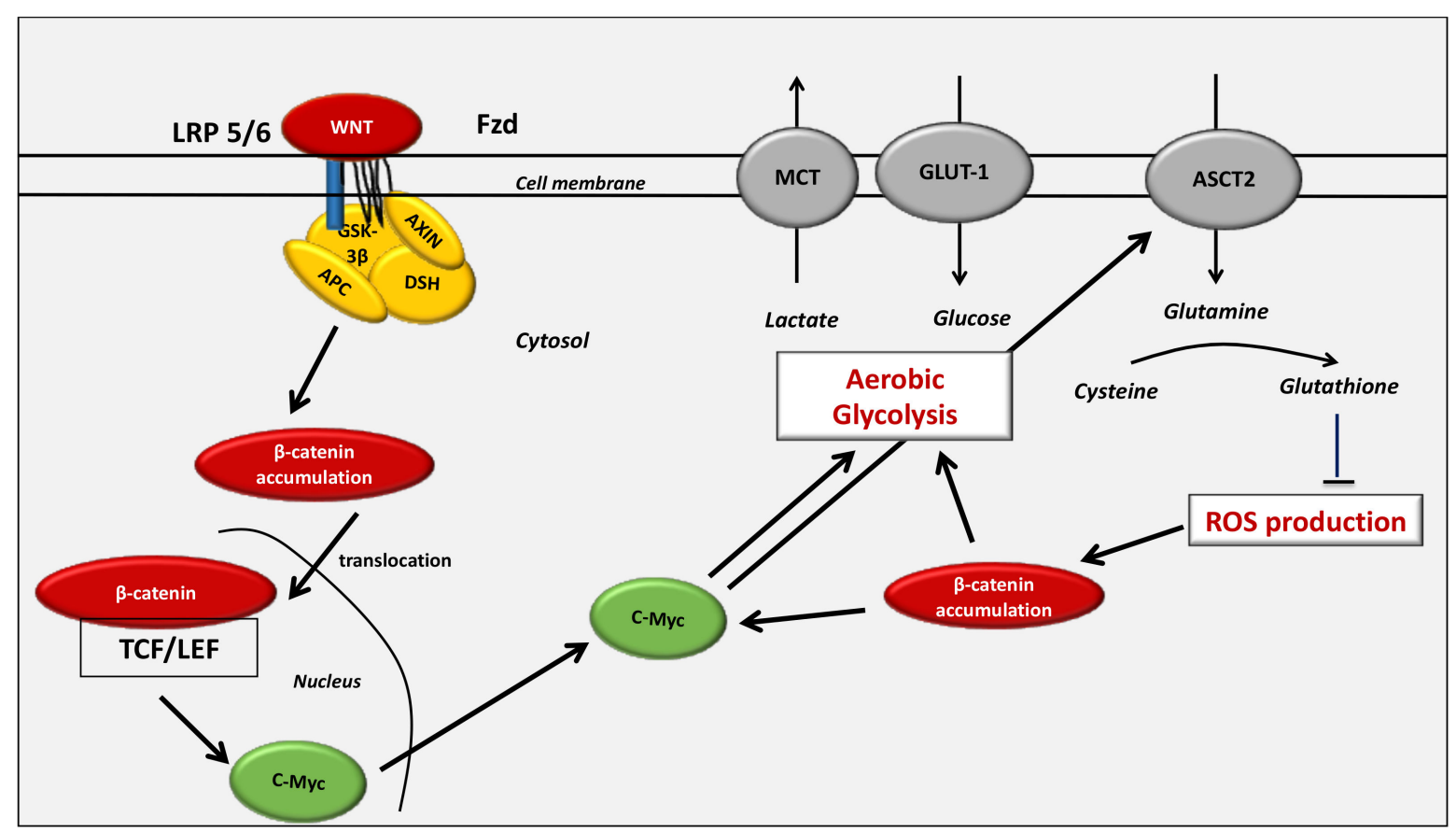

Figure 5. Interplay between the WNT/ $\beta$-catenin pathway, aerobic glycolysis and glutaminolysis. c-Myc has been observed to play a role in the activation of genes involved in glutamine metabolism, including the glutamine transporter ASCT2 (or SLC1A1) and glutaminase [271]. Moreover, $\beta$-catenin can control glutamine metabolism and glutaminolysis by directly acting on c-Myc [272]. Aerobic glycolysis, directly modulated by the WNT/ $\beta$-catenin pathway stimulates the different receptors of the glycose pathway and activates the MCT (monocarboxylate transporters) to translocate the lactate over the cell. The process of glutaminolysis, indirectly activated by the aerobic glycolysis and $\beta$-catenin signaling leads to the down-production of ROS, which in turn activates the $\beta$-catenin. Abbreviations: MCT: monocarboxylate transporter, Glut-1: glucose transporter 1, ASCT2: glutamine transporter 2, ROS: reactive oxygen species.

GSH, a direct product of glutamine metabolism, plays a key role in the chemoresistance of tumor cells [273] and cancer stem cells (CSCs) [274]. GSH is directly associated with the WNT / $\beta$-catenin signaling [275]. The role of GSH is essential in CSC chemoresistance, as it has been observed that CD44+, a CSC surface marker, in association with glutaminecysteine transporter, enhances GSH synthesis [274]. GSH protects the cells against OS by inhibiting ROS production [276]. Therapy with the GSH inhibitor can downregulate tumor growth in mouse models [277]. Deprivation of glutamine in CSCs leads to a decrease in GSH and an increase in $\beta$-catenin phosphorylation, leading to the inhibition of the $\mathrm{WNT} / \beta$-catenin pathway. The regulation of glutamine in stem-like cancer cells can occur through ROS-mediated $\beta$-catenin phosphorylation and proteasomal degradation [275]. Thus, the production of GSH may participate in the decrease of the CSC by decreasing $\mathrm{WNT} / \beta$-catenin pathway activity. Thus, c-Myc is not damaged by a glutamine withdrawal in these types of cancer stem cells, indicating no feedback loop in the c-Myc control of glutamine metabolism [275].

\section{Interaction between the WNT/ $\beta$-Catenin Pathway and the Hippo Pathway: The Link between Glycolysis and Glutaminolysis}

Yes-associated protein 1 (YAP) / transcription coactivator and PDZ-binding motif (TAZ) are transcription co-activators of the Hippo kinase complex [278]. The Hippo pathway modulates organ size and cellular regeneration and involves several compounds such as serine/threonine protein kinases (MST1/2), MOB kinase activator 1 (MOB1), Salvador 
(SAV) and the serine/threonine protein kinase-(LATS1/2). When the kinase Hippo is in the stimulated stage, YAP and TAZ are phosphorylated and involve a phosphodegron. $\mathrm{YAP} / \mathrm{TAZ}$ can be sequestered into the cytoplasm or destroyed by $\beta$-TrCP proteins. The stimulated Hippo pathway results in the phosphorylation of YAP and the reduction of $\beta$-catenin levels.

There is interplay between the WNT/ $\beta$-catenin signaling and the YAP/TAZ signaling. The YAP/TAZ pathway is responsible for WNT-induced biological mechanisms $[279,280]$, while $\beta$-catenin stabilization is responsible for the nuclear TAZ accumulation and its transcriptional activity [279]. In cancer cells, the main part of the transcriptional activity of the WNT target genes is TAZ-dependent. This means that the YAP/TAZ pathway is an integral compound of the $\beta$-catenin destruction complex [280].

APC binds with SAV1 and LATS1, which are upstream controllers of YAP/TAZ. The modulation of the YAP/TAZ pathway by APC is a major reason for intestinal tumor progression. Furthermore, DVL is required for the nucleocytoplasmic shuttling of YAP [281]. WNT activates the YAP/TAZ pathway by FZD overexpression [282]. YAP can also be a direct transcriptional target of the WNT / $\beta$-catenin pathway in tumor cells [283]. WNT3a promotes the TGF- $\beta 1$ pathway through Smad2 phosphorylation [284] (Figure 6).

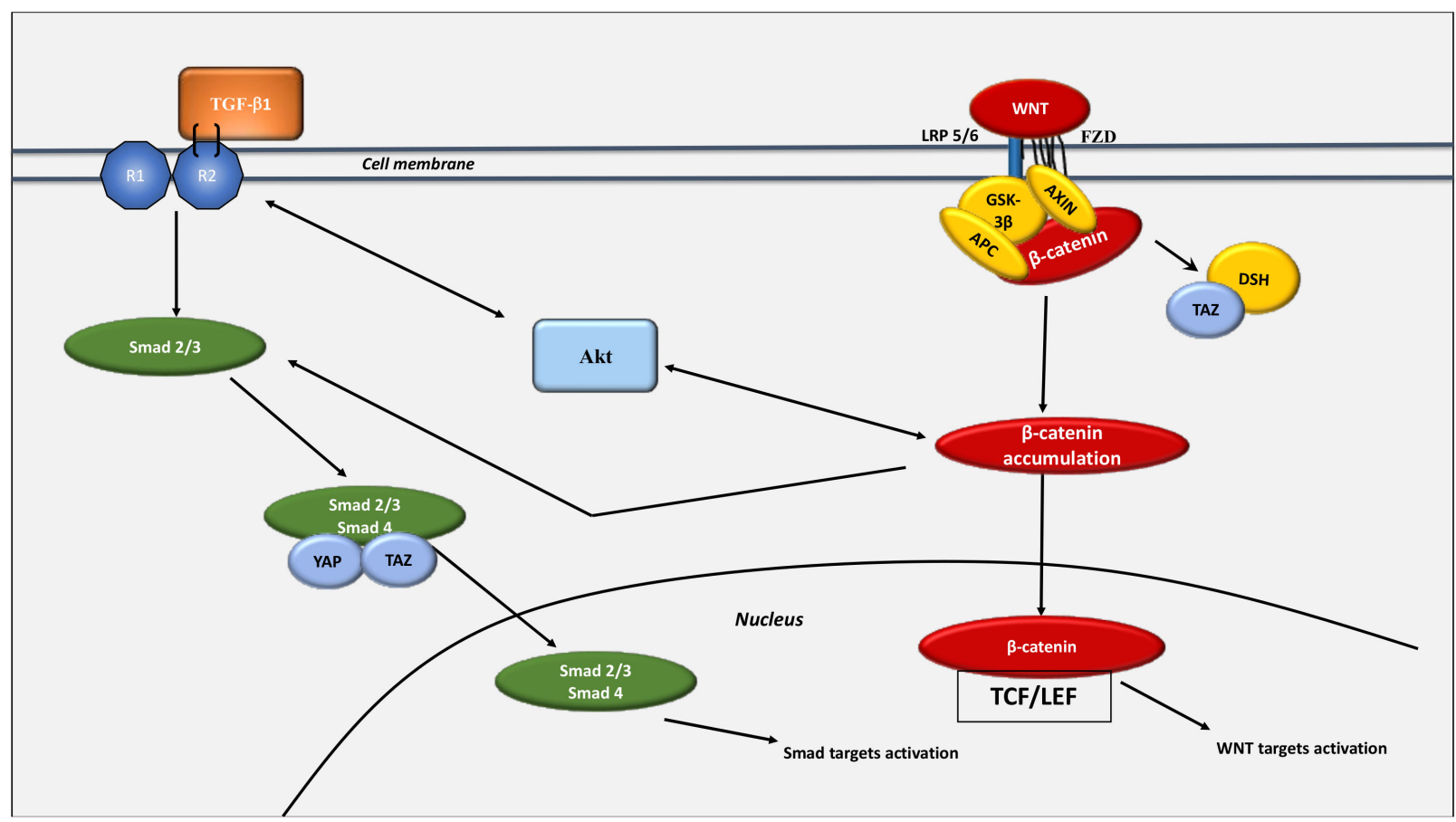

Figure 6. Interaction between the WNT/ $\beta$-catenin pathway and the Hippo pathway. Crosstalk between the YAP/TAZ and TGF- $\beta$ pathways is observed. TAZ interacts with Smad2/Smad3 [285] to induce the nuclear transfer of Smad2/3 and then to transcribe the PAI- 1 and Smad target genes. In the cytosol, TAZ is bound to the WNT/ $\beta$-catenin signaling by a TAZ/ $\beta$ catenin complex [279]. WNT stimulation is associated with the inhibition of the $\beta$-catenin destruction complex, resulting in cytosolic $\beta$-catenin accumulation and its nuclear translocation for stimulating the different WNT targets. Following WNT activation, TAZ decreases the DSH phosphorylation and liberates it from the destruction complex. The destruction complex is destroyed because YAP and TAZ dissociate from the complex. Following TGF- $\beta 1$ stimulation, AXIN leads to the enhancement of the tail-phosphorylation of Smad2/3. The stimulated Smad2/3-Smad4 complex interacts with TAZ and YAP and translocates to the nucleus for the stimulation of the Smad targets. TGF- $\beta 1$ leads to Smad2/3 and PI3K/Akt signaling overactivation. The nuclear translocation of $\beta$-catenin blocks the degradation of TAZ. This relationship of TAZ with the WNT/ $\beta$-catenin pathway is independent of its role as a mediator of the Hippo pathway. When WNT/ $\beta$-catenin signaling activity is decreased, the cytoplasmic YAP/TAZ specifically interacts with AXIN [280].

Activation of YAP/TAZ leads to stimulation of glutamine levels, to the enhancement of nucleotide synthesis, and to the promotion of glutamine synthetase (GS) expression [286]. 
The stimulation of YAP/TAZ modulates metabolic enzyme expression, including that of glutaminase (GLS1), to control both glutaminolysis and glycolysis [287]. The diminution of $\mathrm{YAP} / \mathrm{TAZ}$ decreases both the production of lactate and the extracellular lactate/pyruvate ratio. YAP/TAZ knockdown also shunts the actions of a stiff extracellular matrix on intracellular glutamine, glutamate and aspartate [288]. However, high rates of YAP pathway activity stimulate the extracellular lactate levels and the lactate/pyruvate ratio, diminish glutamine expression and stimulate glutamate and aspartate expression [287].

The stimulation of YAP/TAZ leads to the enhancement of glycolysis in cancer cells. YAP-5SA activates YAP [289], stimulates the glucose uptake and the production of lactate in cells and also presents lower $\mathrm{pH}$ values [290]. Activated YAP involves the transcription activity and expression of GLUT3. YAP leads to the promotion of glycolysis in cancer cells through the direct control of GLUT3 transcription [290]. YAP is enhanced by the forkhead box protein $\mathrm{C} 2$ (FOXC2). The activation of YAP positively regulates the expression of HK2 at both mRNA and protein levels [291]. FOXC2 can interact through a crossbridge to bind with YAP to both stimulate HK2 and enhance glycolysis in cancer cells [291]. The YAP/TAZ pathway is a major metabolic process in the control of glycolysis [287].

\section{Conclusions}

The WNT / $\beta$-catenin pathway is over-activated in several cancers and plays a major role in proliferation, invasion, apoptosis and angiogenesis. Moreover, the nuclear $\beta$-catenin levels are associated with malignancies. Hypoxia is a well-known process that activates HIF- $1 \alpha$ to promote the glycolysis metabolism. The WNT/ $\beta$-catenin pathway stimulates the PI3K/Akt and STAT3 pathways and the transduction of several target genes, including c-Myc, which can stimulate HIF- $1 \alpha$ in a hypoxia-independent manner. In cancers, the stimulation of the WNT/ $\beta$-catenin pathway leads to many glycolytic enzymes that in turn induce metabolic reprogramming (the Warburg effect) in association with autophagy modification. This metabolic reprogramming leads to the production of lactate, as the primary alternative of ATP, at all oxygen rates, even under normoxia. An increase in lactate production is correlated with the modification of the tumor microenvironment, the Warburg effect, autophagy and glutaminolysis, leading to tumor growth under normoxic conditions.

Author Contributions: Conceptualization, A.V.; validation, A.V., Y.L. and J.-N.V.; writing-original draft preparation, A.V.; writing-review and editing, A.V., Y.L. and J.-N.V. All authors have read and agreed to the published version of the manuscript.

Funding: This research received no external funding.

Acknowledgments: The authors would like to thank Brian Keogh, for proofreading and English correction.

Conflicts of Interest: The authors declare no conflict of interest.

\section{Abbreviations}

$\begin{array}{ll}\text { APC } & \text { Adenomatous polyposis coli } \\ \text { CK1 } & \text { casein kinase 1 } \\ \text { COX-2 } & \text { Cyclooxygenase-2 } \\ \text { FZD } & \text { Frizzled } \\ \text { GSK-3 } \beta & \text { Glycogen synthase kinase-3 } \beta \\ \text { LRP 5/6 } & \text { Low-density lipoprotein receptor-related protein 5/6 } \\ \text { MAPK } & \text { Mitogen-activated protein kinases } \\ \text { NF-kB } & \text { nuclear factor } \text { kB } \\ \text { NOX } & \text { NADPH oxidase } \\ \text { PPAR } \gamma & \text { Peroxisome proliferator-activated receptor gamma } \\ \text { PI3K-Akt } & \text { Phosphatidylinositol 3-kinase-protein kinase B } \\ \text { ROS } & \text { reactive oxygen species } \\ \text { TCF/LEF } & \text { T-cell factor/lymphoid enhancer factor } \\ \text { TNF- } \alpha & \text { tumor necrosis factor alpha. }\end{array}$




\section{References}

1. Liu, L.; Lu, Y.; Martinez, J.; Bi, Y.; Lian, G.; Wang, T.; Milasta, S.; Wang, J.; Yang, M.; Liu, G.; et al. Proinflammatory Signal Suppresses Proliferation and Shifts Macrophage Metabolism from Myc-Dependent to HIF1 $\alpha$-Dependent. Proc. Natl. Acad. Sci. USA 2016, 113, 1564-1569. [CrossRef] [PubMed]

2. Semenza, G.L. Hypoxia-Inducible Factors: Coupling Glucose Metabolism and Redox Regulation with Induction of the Breast Cancer Stem Cell Phenotype. EMBO J. 2017, 36, 252-259. [CrossRef] [PubMed]

3. Ryter, S.W.; Choi, A.M.K. Autophagy in Lung Disease Pathogenesis and Therapeutics. Redox Biol. 2015, 4, 215-225. [CrossRef] [PubMed]

4. Kimmelman, A.C.; White, E. Autophagy and Tumor Metabolism. Cell Metab. 2017, 25, 1037-1043. [CrossRef]

5. Warburg, O. On the Origin of Cancer Cells. Science 1956, 123, 309-314. [CrossRef]

6. Fu, H.; Gao, H.; Qi, X.; Zhao, L.; Wu, D.; Bai, Y.; Li, H.; Liu, X.; Hu, J.; Shao, S. Aldolase A Promotes Proliferation and G1/S Transition via the EGFR/MAPK Pathway in Non-Small Cell Lung Cancer. Cancer Commun. 2018, 38, 18. [CrossRef]

7. Liu, T.; Yin, H. PDK1 Promotes Tumor Cell Proliferation and Migration by Enhancing the Warburg Effect in Non-Small Cell Lung Cancer. Oncol. Rep. 2017, 37, 193-200. [CrossRef]

8. Gong, T.; Cui, L.; Wang, H.; Wang, H.; Han, N. Knockdown of KLF5 Suppresses Hypoxia-Induced Resistance to Cisplatin in NSCLC Cells by Regulating HIF-1 $\alpha$-Dependent Glycolysis through Inactivation of the PI3K/Akt/MTOR Pathway. J. Transl. Med. 2018, 16, 164. [CrossRef]

9. Li, L.; Liu, H.; Du, L.; Xi, P.; Wang, Q.; Li, Y.; Liu, D. MiR-449a Suppresses LDHA-Mediated Glycolysis to Enhance the Sensitivity of Non-Small Cell Lung Cancer Cells to Ionizing Radiation. Oncol. Res. 2018, 26, 547-556. [CrossRef]

10. Giatromanolaki, A.; Sivridis, E.; Arelaki, S.; Koukourakis, M.I. Expression of Enzymes Related to Glucose Metabolism in Non-Small Cell Lung Cancer and Prognosis. Exp. Lung Res. 2017, 43, 167-174. [CrossRef]

11. Patel, S.; Alam, A.; Pant, R.; Chattopadhyay, S. Wnt Signaling and Its Significance Within the Tumor Microenvironment: Novel Therapeutic Insights. Front. Immunol. 2019, 10, 2872. [CrossRef]

12. Lecarpentier, Y.; Claes, V.; Vallée, A.; Hébert, J.-L. Thermodynamics in Cancers: Opposing Interactions between PPAR Gamma and the Canonical WNT/Beta-Catenin Pathway. Clin. Transl. Med. 2017, 6, 14. [CrossRef]

13. Lecarpentier, Y.; Schussler, O.; Hébert, J.-L.; Vallée, A. Multiple Targets of the Canonical WNT/ $\beta$-Catenin Signaling in Cancers. Front. Oncol. 2019, 9, 1248. [CrossRef]

14. Vallée, A.; Lecarpentier, Y.; Guillevin, R.; Vallée, J.-N. Thermodynamics in Gliomas: Interactions between the Canonical WNT/Beta-Catenin Pathway and PPAR Gamma. Front. Physiol. 2017, 8, 352. [CrossRef]

15. Vallée, A.; Lecarpentier, Y.; Guillevin, R.; Vallée, J.-N. Opposite Interplay Between the Canonical WNT/ $\beta$-Catenin Pathway and PPAR Gamma: A Potential Therapeutic Target in Gliomas. Neurosci. Bull. 2018, 34, 573-588. [CrossRef]

16. Vallée, A.; Lecarpentier, Y. Crosstalk Between Peroxisome Proliferator-Activated Receptor Gamma and the Canonical WNT/ $\beta$ Catenin Pathway in Chronic Inflammation and Oxidative Stress During Carcinogenesis. Front. Immunol. 2018, 9, 745. [CrossRef]

17. Vallée, A.; Guillevin, R.; Vallée, J.-N. Vasculogenesis and Angiogenesis Initiation under Normoxic Conditions through Wnt/ $\beta$ Catenin Pathway in Gliomas. Rev. Neurosci. 2018, 29, 71-91. [CrossRef]

18. Weinberg, F.; Hamanaka, R.; Wheaton, W.W.; Weinberg, S.; Joseph, J.; Lopez, M.; Kalyanaraman, B.; Mutlu, G.M.; Budinger, G.R.S.; Chandel, N.S. Mitochondrial Metabolism and ROS Generation Are Essential for Kras-Mediated Tumorigenicity. Proc. Natl. Acad. Sci. USA 2010, 107, 8788-8793. [CrossRef]

19. Ma, B.; Hottiger, M.O. Crosstalk between Wnt/ $\beta$-Catenin and NF-KB Signaling Pathway during Inflammation. Front. Immunol. 2016, 7, 378. [CrossRef]

20. Semenza, G.L. HIF-1: Upstream and Downstream of Cancer Metabolism. Curr. Opin. Genet. Dev. 2010, 20, 51-56. [CrossRef]

21. Zhou, W.; Liotta, L.A.; Petricoin, E.F. The Warburg Effect and Mass Spectrometry-Based Proteomic Analysis. Cancer Genom. Proteom. 2017, 14, 211-218. [CrossRef]

22. Vaupel, P. Hypoxia in Neoplastic Tissue. Microvasc. Res. 1977, 13, 399-408. [CrossRef]

23. Vaupel, P.; Fortmeyer, H.P.; Runkel, S.; Kallinowski, F. Blood Flow, Oxygen Consumption, and Tissue Oxygenation of Human Breast Cancer Xenografts in Nude Rats. Cancer Res. 1987, 47, 3496-3503.

24. Vaupel, P.; Mayer, A. Tumor Oxygenation Status: Facts and Fallacies. Adv. Exp. Med. Biol. 2017, 977, 91-99. [CrossRef]

25. Vaupel, P.; Mayer, A. Availability, Not Respiratory Capacity Governs Oxygen Consumption of Solid Tumors. Int. J. Biochem. Cell Biol. 2012, 44, 1477-1481. [CrossRef] [PubMed]

26. Boland, M.L.; Chourasia, A.H.; Macleod, K.F. Mitochondrial Dysfunction in Cancer. Front. Oncol. 2013, 3, 292. [CrossRef] [PubMed]

27. Sabharwal, S.S.; Schumacker, P.T. Mitochondrial ROS in Cancer: Initiators, Amplifiers or an Achilles' Heel? Nat. Rev. Cancer 2014, 14, 709-721. [CrossRef] [PubMed]

28. Denko, N.C. Hypoxia, HIF1 and Glucose Metabolism in the Solid Tumour. Nat. Rev. Cancer 2008, 8, 705-713. [CrossRef]

29. Hanahan, D.; Weinberg, R.A. Hallmarks of Cancer: The next Generation. Cell 2011, 144, 646-674. [CrossRef]

30. Marín-Hernández, A.; Gallardo-Pérez, J.C.; Ralph, S.J.; Rodríguez-Enríquez, S.; Moreno-Sánchez, R. HIF-1alpha Modulates Energy Metabolism in Cancer Cells by Inducing over-Expression of Specific Glycolytic Isoforms. Mini Rev. Med. Chem. 2009, 9, 1084-1101. [CrossRef] 
31. Tran, Q.; Lee, H.; Park, J.; Kim, S.-H.; Park, J. Targeting Cancer Metabolism-Revisiting the Warburg Effects. Toxicol. Res. 2016, 32, 177-193. [CrossRef]

32. Lu, J.; Tan, M.; Cai, Q. The Warburg Effect in Tumor Progression: Mitochondrial Oxidative Metabolism as an Anti-Metastasis Mechanism. Cancer Lett. 2015, 356, 156-164. [CrossRef]

33. Sporn, M.B.; Liby, K.T. NRF2 and Cancer: The Good, the Bad and the Importance of Context. Nat. Rev. Cancer 2012, 12, 564-571. [CrossRef]

34. Vaupel, P.; Schmidberger, H.; Mayer, A. The Warburg Effect: Essential Part of Metabolic Reprogramming and Central Contributor to Cancer Progression. Int. J. Radiat. Biol. 2019, 95, 912-919. [CrossRef]

35. Liao, Y. Cancer Metabolism as We Know It Today: A Prologue to a Special Issue of Cancer Metabolism. Genes Dis. 2017, 4, 4-6. [CrossRef]

36. Gatenby, R.A.; Gawlinski, E.T.; Gmitro, A.F.; Kaylor, B.; Gillies, R.J. Acid-Mediated Tumor Invasion: A Multidisciplinary Study. Cancer Res. 2006, 66, 5216-5223. [CrossRef]

37. Baumann, F.; Leukel, P.; Doerfelt, A.; Beier, C.P.; Dettmer, K.; Oefner, P.J.; Kastenberger, M.; Kreutz, M.; Nickl-Jockschat, T.; Bogdahn, U.; et al. Lactate Promotes Glioma Migration by TGF-Beta2-Dependent Regulation of Matrix Metalloproteinase-2. Neuro-Oncology 2009, 11, 368-380. [CrossRef]

38. Seliger, C.; Leukel, P.; Moeckel, S.; Jachnik, B.; Lottaz, C.; Kreutz, M.; Brawanski, A.; Proescholdt, M.; Bogdahn, U.; Bosserhoff, A.-K.; et al. Lactate-Modulated Induction of THBS-1 Activates Transforming Growth Factor (TGF)-Beta2 and Migration of Glioma Cells in Vitro. PLoS ONE 2013, 8, e78935. [CrossRef]

39. Fischer, K.; Hoffmann, P.; Voelkl, S.; Meidenbauer, N.; Ammer, J.; Edinger, M.; Gottfried, E.; Schwarz, S.; Rothe, G.; Hoves, S.; et al. Inhibitory Effect of Tumor Cell-Derived Lactic Acid on Human T Cells. Blood 2007, 109, 3812-3819. [CrossRef]

40. Gottfried, E.; Kunz-Schughart, L.A.; Ebner, S.; Mueller-Klieser, W.; Hoves, S.; Andreesen, R.; Mackensen, A.; Kreutz, M. Tumor-Derived Lactic Acid Modulates Dendritic Cell Activation and Antigen Expression. Blood 2006, 107, 2013-2021. [CrossRef]

41. Kondoh, H.; Lleonart, M.E.; Gil, J.; Wang, J.; Degan, P.; Peters, G.; Martinez, D.; Carnero, A.; Beach, D. Glycolytic Enzymes Can Modulate Cellular Life Span. Cancer Res. 2005, 65, 177-185.

42. Végran, F.; Boidot, R.; Michiels, C.; Sonveaux, P.; Feron, O. Lactate Influx through the Endothelial Cell Monocarboxylate Transporter MCT1 Supports an NF-KB/IL-8 Pathway That Drives Tumor Angiogenesis. Cancer Res. 2011, 71, 2550-2560. [CrossRef]

43. Constant, J.S.; Feng, J.J.; Zabel, D.D.; Yuan, H.; Suh, D.Y.; Scheuenstuhl, H.; Hunt, T.K.; Hussain, M.Z. Lactate Elicits Vascular Endothelial Growth Factor from Macrophages: A Possible Alternative to Hypoxia. Wound Repair Regen. Off. Publ. Wound Health Soc. Eur. Tissue Repair Soc. 2000, 8, 353-360. [CrossRef]

44. D'Arcangelo, D.; Facchiano, F.; Barlucchi, L.M.; Melillo, G.; Illi, B.; Testolin, L.; Gaetano, C.; Capogrossi, M.C. Acidosis Inhibits Endothelial Cell Apoptosis and Function and Induces Basic Fibroblast Growth Factor and Vascular Endothelial Growth Factor Expression. Circ. Res. 2000, 86, 312-318. [CrossRef]

45. Goerges, A.L.; Nugent, M.A. PH Regulates Vascular Endothelial Growth Factor Binding to Fibronectin: A Mechanism for Control of Extracellular Matrix Storage and Release. J. Biol. Chem. 2004, 279, 2307-2315. [CrossRef]

46. Jensen, J.A.; Hunt, T.K.; Scheuenstuhl, H.; Banda, M.J. Effect of Lactate, Pyruvate, and PH on Secretion of Angiogenesis and Mitogenesis Factors by Macrophages. Lab. Investig. J. Tech. Methods Pathol. 1986, 54, 574-578.

47. Sattler, U.G.A.; Meyer, S.S.; Quennet, V.; Hoerner, C.; Knoerzer, H.; Fabian, C.; Yaromina, A.; Zips, D.; Walenta, S.; Baumann, M.; et al. Glycolytic Metabolism and Tumour Response to Fractionated Irradiation. Radiother. Oncol. J. Eur. Soc. Ther. Radiol. Oncol. 2010, 94, 102-109. [CrossRef]

48. Xu, L.; Fukumura, D.; Jain, R.K. Acidic Extracellular PH Induces Vascular Endothelial Growth Factor (VEGF) in Human Glioblastoma Cells via ERK1/2 MAPK Signaling Pathway: Mechanism of Low PH-Induced VEGF. J. Biol. Chem. 2002, 277, 11368-11374. [CrossRef]

49. Zadeh, G.; Koushan, K.; Pillo, L.; Shannon, P.; Guha, A. Role of Ang1 and Its Interaction with VEGF-A in Astrocytomas. J. Neuropathol. Exp. Neurol. 2004, 63, 978-989. [CrossRef]

50. Griffiths, J.R. Are Cancer Cells Acidic? Br. J. Cancer 1991, 64, 425-427. [CrossRef]

51. Raghunand, N.; Gatenby, R.A.; Gillies, R.J. Microenvironmental and Cellular Consequences of Altered Blood Flow in Tumours. Br. J. Radiol. 2003, 76, S11-S22. [CrossRef] [PubMed]

52. Wike-Hooley, J.L.; Haveman, J.; Reinhold, H.S. The Relevance of Tumour PH to the Treatment of Malignant Disease. Radiother. Oncol. J. Eur. Soc. Ther. Radiol. Oncol. 1984, 2, 343-366. [CrossRef]

53. Shi, Q.; Le, X.; Wang, B.; Abbruzzese, J.L.; Xiong, Q.; He, Y.; Xie, K. Regulation of Vascular Endothelial Growth Factor Expression by Acidosis in Human Cancer Cells. Oncogene 2001, 20, 3751-3756. [CrossRef] [PubMed]

54. Fukumura, D.; Xu, L.; Chen, Y.; Gohongi, T.; Seed, B.; Jain, R.K. Hypoxia and Acidosis Independently Up-Regulate Vascular Endothelial Growth Factor Transcription in Brain Tumors in Vivo. Cancer Res. 2001, 61, 6020-6024. [PubMed]

55. Chang, L.K.; Garcia-Cardena, G.; Farnebo, F.; Fannon, M.; Chen, E.J.; Butterfield, C.; Moses, M.A.; Mulligan, R.C.; Folkman, J.; Kaipainen, A. Dose-Dependent Response of FGF-2 for Lymphangiogenesis. Proc. Natl. Acad. Sci. USA 2004, 101, 11658-11663. [CrossRef] [PubMed]

56. Eichten, A.; Hyun, W.C.; Coussens, L.M. Distinctive Features of Angiogenesis and Lymphangiogenesis Determine Their Functionality during de Novo Tumor Development. Cancer Res. 2007, 67, 5211-5220. [CrossRef] 
57. Hunt, T.K.; Aslam, R.S.; Beckert, S.; Wagner, S.; Ghani, Q.P.; Hussain, M.Z.; Roy, S.; Sen, C.K. Aerobically Derived Lactate Stimulates Revascularization and Tissue Repair via Redox Mechanisms. Antioxid. Redox Signal. 2007, 9, 1115-1124. [CrossRef]

58. Milovanova, T.N.; Bhopale, V.M.; Sorokina, E.M.; Moore, J.S.; Hunt, T.K.; Hauer-Jensen, M.; Velazquez, O.C.; Thom, S.R. Lactate Stimulates Vasculogenic Stem Cells via the Thioredoxin System and Engages an Autocrine Activation Loop Involving Hypoxia-Inducible Factor 1. Mol. Cell. Biol. 2008, 28, 6248-6261. [CrossRef]

59. Haaga, J.R.; Haaga, R. Acidic Lactate Sequentially Induced Lymphogenesis, Phlebogenesis, and Arteriogenesis (ALPHA) Hypothesis: Lactate-Triggered Glycolytic Vasculogenesis That Occurs in Normoxia or Hypoxia and Complements the Traditional Concept of Hypoxia-Based Vasculogenesis. Surgery 2013, 154, 632-637. [CrossRef]

60. Lu, H.; Forbes, R.A.; Verma, A. Hypoxia-Inducible Factor 1 Activation by Aerobic Glycolysis Implicates the Warburg Effect in Carcinogenesis. J. Biol. Chem. 2002, 277, 23111-23115. [CrossRef]

61. Lu, H.; Dalgard, C.L.; Mohyeldin, A.; McFate, T.; Tait, A.S.; Verma, A. Reversible Inactivation of HIF-1 Prolyl Hydroxylases Allows Cell Metabolism to Control Basal HIF-1. J. Biol. Chem. 2005, 280, 41928-41939. [CrossRef]

62. McFate, T.; Mohyeldin, A.; Lu, H.; Thakar, J.; Henriques, J.; Halim, N.D.; Wu, H.; Schell, M.J.; Tsang, T.M.; Teahan, O.; et al. Pyruvate Dehydrogenase Complex Activity Controls Metabolic and Malignant Phenotype in Cancer Cells. J. Biol. Chem. 2008, 283, 22700-22708. [CrossRef]

63. Mekhail, K.; Khacho, M.; Carrigan, A.; Hache, R.R.J.; Gunaratnam, L.; Lee, S. Regulation of Ubiquitin Ligase Dynamics by the Nucleolus. J. Cell Biol. 2005, 170, 733-744. [CrossRef]

64. Kaur, B.; Tan, C.; Brat, D.J.; Post, D.E.; Van Meir, E.G. Genetic and Hypoxic Regulation of Angiogenesis in Gliomas. J. Neurooncol. 2004, 70, 229-243. [CrossRef]

65. Ohgaki, H.; Dessen, P.; Jourde, B.; Horstmann, S.; Nishikawa, T.; Di Patre, P.-L.; Burkhard, C.; Schüler, D.; Probst-Hensch, N.M.; Maiorka, P.C.; et al. Genetic Pathways to Glioblastoma: A Population-Based Study. Cancer Res. 2004, 64, 6892-6899. [CrossRef]

66. Parliament, M.B.; Allalunis-Turner, M.J.; Franko, A.J.; Olive, P.L.; Mandyam, R.; Santos, C.; Wolokoff, B. Vascular Endothelial Growth Factor Expression Is Independent of Hypoxia in Human Malignant Glioma Spheroids and Tumours. Br. J. Cancer 2000, 82, 635-641. [CrossRef]

67. Semenza, G.L. Defining the Role of Hypoxia-Inducible Factor 1 in Cancer Biology and Therapeutics. Oncogene 2010, 29 , 625-634. [CrossRef]

68. Zagzag, D.; Zhong, H.; Scalzitti, J.M.; Laughner, E.; Simons, J.W.; Semenza, G.L. Expression of Hypoxia-Inducible Factor 1alpha in Brain Tumors: Association with Angiogenesis, Invasion, and Progression. Cancer 2000, 88, 2606-2618. [CrossRef]

69. Semenza, G.L. Targeting HIF-1 for Cancer Therapy. Nat. Rev. Cancer 2003, 3, 721-732. [CrossRef]

70. Brahimi-Horn, M.C.; Chiche, J.; Pouysségur, J. Hypoxia and Cancer. J. Mol. Med. Berl. Ger. 2007, 85, 1301-1307. [CrossRef]

71. Unruh, A.; Ressel, A.; Mohamed, H.G.; Johnson, R.S.; Nadrowitz, R.; Richter, E.; Katschinski, D.M.; Wenger, R.H. The HypoxiaInducible Factor-1 Alpha Is a Negative Factor for Tumor Therapy. Oncogene 2003, 22, 3213-3220. [CrossRef]

72. Green, H.; Goldberg, B. Collagen and Cell Protein Synthesis by an Established Mammalian Fibroblast Line. Nature 1964, 204, 347-349. [CrossRef]

73. Dhup, S.; Dadhich, R.K.; Porporato, P.E.; Sonveaux, P. Multiple Biological Activities of Lactic Acid in Cancer: Influences on Tumor Growth, Angiogenesis and Metastasis. Curr. Pharm. Des. 2012, 18, 1319-1330. [CrossRef]

74. Polet, F.; Feron, O. Endothelial Cell Metabolism and Tumour Angiogenesis: Glucose and Glutamine as Essential Fuels and Lactate as the Driving Force. J. Intern. Med. 2013, 273, 156-165. [CrossRef]

75. San-Millán, I.; Brooks, G.A. Reexamining cancer metabolism: Lactate production for carcinogenesis could be the purpose and explanation of the Warburg Effect. Carcinogenesis 2016, 38, 119-133. [CrossRef]

76. De Saedeleer, C.J.; Copetti, T.; Porporato, P.E.; Verrax, J.; Feron, O.; Sonveaux, P. Lactate Activates HIF-1 in Oxidative but Not in Warburg-Phenotype Human Tumor Cells. PLoS ONE 2012, 7, e46571. [CrossRef]

77. Hashimoto, T.; Hussien, R.; Oommen, S.; Gohil, K.; Brooks, G.A. Lactate Sensitive Transcription Factor Network in L6 Cells: Activation of MCT1 and Mitochondrial Biogenesis. FASEB J. Off. Publ. Fed. Am. Soc. Exp. Biol. 2007, 21, 2602-2612. [CrossRef] [PubMed]

78. Sonveaux, P.; Copetti, T.; De Saedeleer, C.J.; Végran, F.; Verrax, J.; Kennedy, K.M.; Moon, E.J.; Dhup, S.; Danhier, P.; Frérart, F.; et al. Targeting the Lactate Transporter MCT1 in Endothelial Cells Inhibits Lactate-Induced HIF-1 Activation and Tumor Angiogenesis. PLOS ONE 2012, 7, e33418. [CrossRef] [PubMed]

79. Kerbel, R.S. Tumor Angiogenesis. N. Engl. J. Med. 2008, 358, 2039-2049. [CrossRef] [PubMed]

80. Vander Heiden, M.G.; Cantley, L.C.; Thompson, C.B. Understanding the Warburg Effect: The Metabolic Requirements of Cell Proliferation. Science 2009, 324, 1029-1033. [CrossRef] [PubMed]

81. Stern, R. Hyaluronidases in Cancer Biology. Semin. Cancer Biol. 2008, 18, 275-280. [CrossRef]

82. Walenta, S.; Mueller-Klieser, W.F. Lactate: Mirror and Motor of Tumor Malignancy. Semin. Radiat. Oncol. 2004, 14, 267-274. [CrossRef]

83. Pardue, E.L.; Ibrahim, S.; Ramamurthi, A. Role of Hyaluronan in Angiogenesis and Its Utility to Angiogenic Tissue Engineering. Organogenesis 2008, 4, 203-214. [CrossRef]

84. Schoenfelder, M.; Einspanier, R. Expression of Hyaluronan Synthases and Corresponding Hyaluronan Receptors Is Differentially Regulated during Oocyte Maturation in Cattle. Biol. Reprod. 2003, 69, 269-277. [CrossRef] 
85. Formby, B.; Stern, R. Lactate-Sensitive Response Elements in Genes Involved in Hyaluronan Catabolism. Biochem. Biophys. Res. Commun. 2003, 305, 203-208. [CrossRef]

86. Stern, R.; Shuster, S.; Neudecker, B.A.; Formby, B. Lactate Stimulates Fibroblast Expression of Hyaluronan and CD44: The Warburg Effect Revisited. Exp. Cell Res. 2002, 276, 24-31. [CrossRef]

87. West, D.C.; Hampson, I.N.; Arnold, F.; Kumar, S. Angiogenesis Induced by Degradation Products of Hyaluronic Acid. Science 1985, 228, 1324-1326. [CrossRef]

88. Genasetti, A.; Vigetti, D.; Viola, M.; Karousou, E.; Moretto, P.; Rizzi, M.; Bartolini, B.; Clerici, M.; Pallotti, F.; De Luca, G.; et al. Hyaluronan and Human Endothelial Cell Behavior. Connect. Tissue Res. 2008, 49, 120-123. [CrossRef]

89. Gao, F.; Yang, C.X.; Mo, W.; Liu, Y.W.; He, Y.Q. Hyaluronan Oligosaccharides Are Potential Stimulators to Angiogenesis via RHAMM Mediated Signal Pathway in Wound Healing. Clin. Investig. Med. Med. Clin. Exp. 2008, 31, E106-E116. [CrossRef]

90. Ohno-Nakahara, M.; Honda, K.; Tanimoto, K.; Tanaka, N.; Doi, T.; Suzuki, A.; Yoneno, K.; Nakatani, Y.; Ueki, M.; Ohno, S.; et al. Induction of CD44 and MMP Expression by Hyaluronidase Treatment of Articular Chondrocytes. J. Biochem. 2004, 135, 567-575. [CrossRef]

91. Zhang, Y.; Thant, A.A.; Machida, K.; Ichigotani, Y.; Naito, Y.; Hiraiwa, Y.; Senga, T.; Sohara, Y.; Matsuda, S.; Hamaguchi, M. Hyaluronan-CD44s Signaling Regulates Matrix Metalloproteinase-2 Secretion in a Human Lung Carcinoma Cell Line QG90. Cancer Res. 2002, 62, 3962-3965.

92. Loh, K.M.; van Amerongen, R.; Nusse, R. Generating Cellular Diversity and Spatial Form: Wnt Signaling and the Evolution of Multicellular Animals. Dev. Cell 2016, 38, 643-655. [CrossRef]

93. Oren, O.; Smith, B.D. Eliminating Cancer Stem Cells by Targeting Embryonic Signaling Pathways. Stem Cell Rev. 2017, 13, 17-23. [CrossRef]

94. Al-Harthi, L. Wnt/ $\beta$-Catenin and Its Diverse Physiological Cell Signaling Pathways in Neurodegenerative and Neuropsychiatric Disorders. J. Neuroimmune Pharmacol. 2012, 7, 725-730. [CrossRef]

95. Marchetti, B.; Pluchino, S. Wnt Your Brain Be Inflamed? Yes, It Wnt! Trends Mol. Med. 2013, 19, 144-156. [CrossRef]

96. Vallée, A.; Lecarpentier, Y.; Guillevin, R.; Vallée, J.-N. Thermodynamics in Neurodegenerative Diseases: Interplay Between Canonical WNT/Beta-Catenin Pathway-PPAR Gamma, Energy Metabolism and Circadian Rhythms. Neuromol. Med. 2018, 20, 174-204. [CrossRef]

97. Lecarpentier, Y.; Claes, V.; Duthoit, G.; Hébert, J.-L. Circadian Rhythms, Wnt/Beta-Catenin Pathway and PPAR Alpha/Gamma Profiles in Diseases with Primary or Secondary Cardiac Dysfunction. Front. Physiol. 2014, 5, 429. [CrossRef]

98. Lecarpentier, Y.; Vallée, A. Opposite Interplay between PPAR Gamma and Canonical Wnt/Beta-Catenin Pathway in Amyotrophic Lateral Sclerosis. Front. Neurol. 2016, 7, 100. [CrossRef]

99. Vallée, A.; Lecarpentier, Y. Alzheimer Disease: Crosstalk between the Canonical Wnt/Beta-Catenin Pathway and PPARs Alpha and Gamma. Front. Neurosci. 2016, 10, 459. [CrossRef]

100. MacDonald, B.T.; He, X. Frizzled and LRP5/6 Receptors for Wnt/ $\beta$-Catenin Signaling. Cold Spring Harb. Perspect. Biol. 2012, 4, a007880. [CrossRef]

101. He, T.C.; Sparks, A.B.; Rago, C.; Hermeking, H.; Zawel, L.; da Costa, L.T.; Morin, P.J.; Vogelstein, B.; Kinzler, K.W. Identification of C-MYC as a Target of the APC Pathway. Science 1998, 281, 1509-1512. [CrossRef] [PubMed]

102. Shtutman, M.; Zhurinsky, J.; Simcha, I.; Albanese, C.; D'Amico, M.; Pestell, R.; Ben-Ze'ev, A. The Cyclin D1 Gene Is a Target of the Beta-Catenin/LEF-1 Pathway. Proc. Natl. Acad. Sci. USA 1999, 96, 5522-5527. [CrossRef] [PubMed]

103. Angers, S.; Moon, R.T. Proximal events in Wnt signal transduction. Nat. Rev. Mol. Cell Biol. 2009, 10, 468-477. [CrossRef] [PubMed]

104. Sharma, C.; Pradeep, A.; Wong, L.; Rana, A.; Rana, B. Peroxisome Proliferator-Activated Receptor Gamma Activation Can Regulate Beta-Catenin Levels via a Proteasome-Mediated and Adenomatous Polyposis Coli-Independent Pathway. J. Biol. Chem. 2004, 279, 35583-35594. [CrossRef] [PubMed]

105. Rosi, M.C.; Luccarini, I.; Grossi, C.; Fiorentini, A.; Spillantini, M.G.; Prisco, A.; Scali, C.; Gianfriddo, M.; Caricasole, A.; Terstappen, G.C.; et al. Increased Dickkopf-1 Expression in Transgenic Mouse Models of Neurodegenerative Disease. J. Neurochem. 2010, 112, 1539-1551. [CrossRef] [PubMed]

106. Clevers, H.; Nusse, R. Wnt/ $\beta$-Catenin Signaling and Disease. Cell 2012, 149, 1192-1205. [CrossRef]

107. Inestrosa, N.C.; Montecinos-Oliva, C.; Fuenzalida, M. Wnt Signaling: Role in Alzheimer Disease and Schizophrenia. J. Neuroimmune Pharmacol. Off. J. Soc. NeuroImmune Pharmacol. 2012, 7, 788-807. [CrossRef]

108. Vallée, A.; Lecarpentier, Y.; Guillevin, R.; Vallée, J.-N. Interactions between TGF-B1, Canonical WNT/ $\beta$-Catenin Pathway and PPAR $\gamma$ in Radiation-Induced Fibrosis. Oncotarget 2017, 8, 90579-90604. [CrossRef]

109. Vallée, A.; Lecarpentier, Y.; Vallée, J.-N. Hypothesis of Opposite Interplay Between the Canonical WNT/Beta-Catenin Pathway and PPAR Gamma in Primary Central Nervous System Lymphomas. Curr. Issues Mol. Biol. 2019, 31, 1-20. [CrossRef]

110. Aberle, H.; Bauer, A.; Stappert, J.; Kispert, A.; Kemler, R. $\beta$-Catenin Is a Target for the Ubiquitin-Proteasome Pathway. EMBO J. 1997, 16, 3797-3804. [CrossRef]

111. Wu, D.; Pan, W. GSK3: A Multifaceted Kinase in Wnt Signaling. Trends Biochem. Sci. 2010, 35, 161-168. [CrossRef]

112. Hur, E.-M.; Zhou, F.-Q. GSK3 Signalling in Neural Development. Nat. Rev. Neurosci. 2010, 11, 539-551. [CrossRef] 
113. Ambacher, K.K.; Pitzul, K.B.; Karajgikar, M.; Hamilton, A.; Ferguson, S.S.; Cregan, S.P. The JNK- and AKT/GSK3 $\beta-$ Signaling Pathways Converge to Regulate Puma Induction and Neuronal Apoptosis Induced by Trophic Factor Deprivation. PLoS ONE 2012, 7, e46885. [CrossRef]

114. Orellana, A.M.M.; Vasconcelos, A.R.; Leite, J.A.; de Sá Lima, L.; Andreotti, D.Z.; Munhoz, C.D.; Kawamoto, E.M.; Scavone, C. Age-Related Neuroinflammation and Changes in AKT-GSK-3 $\beta$ and WNT/ $\beta$-CATENIN Signaling in Rat Hippocampus. Aging 2015, 7, 1094-1111. [CrossRef]

115. Jha, M.K.; Suk, K. Pyruvate Dehydrogenase Kinase as a Potential Therapeutic Target for Malignant Gliomas. Brain Tumor Res. Treat. 2013, 1, 57-63. [CrossRef]

116. Thompson, C.B. Wnt Meets Warburg: Another Piece in the Puzzle? EMBO J. 2014, 33, 1420-1422. [CrossRef]

117. Pate, K.T.; Stringari, C.; Sprowl-Tanio, S.; Wang, K.; TeSlaa, T.; Hoverter, N.P.; McQuade, M.M.; Garner, C.; Digman, M.A.; Teitell, M.A.; et al. Wnt Signaling Directs a Metabolic Program of Glycolysis and Angiogenesis in Colon Cancer. EMBO J. 2014, 33, 1454-1473. [CrossRef]

118. Venneti, S.; Thompson, C.B. Metabolic Reprogramming in Brain Tumors. Annu. Rev. Pathol. 2017, 12, 515-545. [CrossRef]

119. Sutendra, G.; Dromparis, P.; Kinnaird, A.; Stenson, T.H.; Haromy, A.; Parker, J.M.R.; McMurtry, M.S.; Michelakis, E.D. Mitochondrial Activation by Inhibition of PDKII Suppresses HIF1a Signaling and Angiogenesis in Cancer. Oncogene 2013, 32, 1638-1650. [CrossRef]

120. Wise, D.R.; DeBerardinis, R.J.; Mancuso, A.; Sayed, N.; Zhang, X.-Y.; Pfeiffer, H.K.; Nissim, I.; Daikhin, E.; Yudkoff, M.; McMahon, S.B.; et al. Myc Regulates a Transcriptional Program That Stimulates Mitochondrial Glutaminolysis and Leads to Glutamine Addiction. Proc. Natl. Acad. Sci. USA 2008, 105, 18782-18787. [CrossRef]

121. Kim, J.; Gao, P.; Liu, Y.-C.; Semenza, G.L.; Dang, C.V. Hypoxia-Inducible Factor 1 and Dysregulated c-Myc Cooperatively Induce Vascular Endothelial Growth Factor and Metabolic Switches Hexokinase 2 and Pyruvate Dehydrogenase Kinase 1. Mol. Cell. Biol. 2007, 27, 7381-7393. [CrossRef] [PubMed]

122. Lum, J.J.; Bui, T.; Gruber, M.; Gordan, J.D.; DeBerardinis, R.J.; Covello, K.L.; Simon, M.C.; Thompson, C.B. The Transcription Factor HIF-1alpha Plays a Critical Role in the Growth Factor-Dependent Regulation of Both Aerobic and Anaerobic Glycolysis. Genes Dev. 2007, 21, 1037-1049. [CrossRef] [PubMed]

123. Sun, Q.; Chen, X.; Ma, J.; Peng, H.; Wang, F.; Zha, X.; Wang, Y.; Jing, Y.; Yang, H.; Chen, R.; et al. Mammalian Target of Rapamycin Up-Regulation of Pyruvate Kinase Isoenzyme Type M2 Is Critical for Aerobic Glycolysis and Tumor Growth. Proc. Natl. Acad. Sci. USA 2011, 108, 4129-4134. [CrossRef] [PubMed]

124. Yeung, S.J.; Pan, J.; Lee, M.-H. Roles of P53, MYC and HIF-1 in Regulating Glycolysis-the Seventh Hallmark of Cancer. Cell. Mol. Life Sci. CMLS 2008, 65, 3981-3999. [CrossRef] [PubMed]

125. Maurer, G.D.; Brucker, D.P.; Bähr, O.; Harter, P.N.; Hattingen, E.; Walenta, S.; Mueller-Klieser, W.; Steinbach, J.P.; Rieger, J. Differential Utilization of Ketone Bodies by Neurons and Glioma Cell Lines: A Rationale for Ketogenic Diet as Experimental Glioma Therapy. BMC Cancer 2011, 11, 315. [CrossRef] [PubMed]

126. Oudard, S.; Arvelo, F.; Miccoli, L.; Apiou, F.; Dutrillaux, A.M.; Poisson, M.; Dutrillaux, B.; Poupon, M.F. High Glycolysis in Gliomas despite Low Hexokinase Transcription and Activity Correlated to Chromosome 10 Loss. Br. J. Cancer 1996, 74, 839-845. [CrossRef]

127. Sancho, P.; Barneda, D.; Heeschen, C. Hallmarks of Cancer Stem Cell Metabolism. Br. J. Cancer 2016, 114, 1305-1312. [CrossRef]

128. Bouzier-Sore, A.K.; Canioni, P.; Merle, M. Effect of Exogenous Lactate on Rat Glioma Metabolism. J. Neurosci. Res. 2001, 65, 543-548. [CrossRef]

129. Darnell, J.E. STATs and Gene Regulation. Science 1997, 277, 1630-1635. [CrossRef]

130. Horvath, C.M. STAT Proteins and Transcriptional Responses to Extracellular Signals. Trends Biochem. Sci. 2000, 25, 496-502. [CrossRef]

131. Schaefer, L.K.; Ren, Z.; Fuller, G.N.; Schaefer, T.S. Constitutive Activation of Stat3alpha in Brain Tumors: Localization to Tumor Endothelial Cells and Activation by the Endothelial Tyrosine Kinase Receptor (VEGFR-2). Oncogene 2002, 21, 2058-2065. [CrossRef]

132. Sinibaldi, D.; Wharton, W.; Turkson, J.; Bowman, T.; Pledger, W.J.; Jove, R. Induction of P21WAF1/CIP1 and Cyclin D1 Expression by the Src Oncoprotein in Mouse Fibroblasts: Role of Activated STAT3 Signaling. Oncogene 2000, 19, 5419-5427. [CrossRef]

133. Jung, J.E.; Lee, H.G.; Cho, I.H.; Chung, D.H.; Yoon, S.-H.; Yang, Y.M.; Lee, J.W.; Choi, S.; Park, J.-W.; Ye, S.-K.; et al. STAT3 Is a Potential Modulator of HIF-1-Mediated VEGF Expression in Human Renal Carcinoma Cells. FASEB J. Off. Publ. Fed. Am. Soc. Exp. Biol. 2005, 19, 1296-1298. [CrossRef]

134. Yan, S.; Zhou, C.; Zhang, W.; Zhang, G.; Zhao, X.; Yang, S.; Wang, Y.; Lu, N.; Zhu, H.; Xu, N. Beta-Catenin/TCF Pathway Upregulates STAT3 Expression in Human Esophageal Squamous Cell Carcinoma. Cancer Lett. 2008, 271, 85-97. [CrossRef]

135. Carro, M.S.; Lim, W.K.; Alvarez, M.J.; Bollo, R.J.; Zhao, X.; Snyder, E.Y.; Sulman, E.P.; Anne, S.L.; Doetsch, F.; Colman, H.; et al. The Transcriptional Network for Mesenchymal Transformation of Brain Tumours. Nature 2010, 463, 318-325. [CrossRef]

136. Ma, J.; Meng, Y.; Kwiatkowski, D.J.; Chen, X.; Peng, H.; Sun, Q.; Zha, X.; Wang, F.; Wang, Y.; Jing, Y.; et al. Mammalian Target of Rapamycin Regulates Murine and Human Cell Differentiation through STAT3/P63/Jagged/Notch Cascade. J. Clin. Investig. 2010, 120, 103-114. [CrossRef] 
137. Mazzone, M.; Selfors, L.M.; Albeck, J.; Overholtzer, M.; Sale, S.; Carroll, D.L.; Pandya, D.; Lu, Y.; Mills, G.B.; Aster, J.C.; et al. Dose-Dependent Induction of Distinct Phenotypic Responses to Notch Pathway Activation in Mammary Epithelial Cells. Proc. Natl. Acad. Sci. USA 2010, 107, 5012-5017. [CrossRef]

138. Kang, S.-H.; Yu, M.O.; Park, K.-J.; Chi, S.-G.; Park, D.-H.; Chung, Y.-G. Activated STAT3 Regulates Hypoxia-Induced Angiogenesis and Cell Migration in Human Glioblastoma. Neurosurgery 2010, 67, 1386-1395. [CrossRef]

139. Chakravarti, A.; Dicker, A.; Mehta, M. The Contribution of Epidermal Growth Factor Receptor (EGFR) Signaling Pathway to Radioresistance in Human Gliomas: A Review of Preclinical and Correlative Clinical Data. Int. J. Radiat. Oncol. 2004, 58, 927-931. [CrossRef]

140. Mellinghoff, I.K.; Wang, M.Y.; Vivanco, I.; Haas-Kogan, D.A.; Zhu, S.; Dia, E.Q.; Lu, K.V.; Yoshimoto, K.; Huang, J.H.Y.; Chute, D.J.; et al. Molecular Determinants of the Response of Glioblastomas to EGFR Kinase Inhibitors. N. Engl. J. Med. 2005, 353, 2012-2024. [CrossRef]

141. Seshacharyulu, P.; Ponnusamy, M.P.; Haridas, D.; Jain, M.; Ganti, A.K.; Batra, S.K. Targeting the EGFR Signaling Pathway in Cancer Therapy. Expert Opin. Ther. Targets 2012, 16, 15-31. [CrossRef] [PubMed]

142. Vogt, P.K.; Hart, J.R. PI3K and STAT3: A New Alliance. Cancer Discov. 2011, 1, 481-486. [CrossRef]

143. Paw, I.; Carpenter, R.C.; Watabe, K.; Debinski, W.; Lo, H.-W. Mechanisms Regulating Glioma Invasion. Cancer Lett. 2015, $362,1-7$. [CrossRef] [PubMed]

144. Sami, A.; Karsy, M. Targeting the PI3K/AKT/MTOR Signaling Pathway in Glioblastoma: Novel Therapeutic Agents and Advances in Understanding. Tumour Biol. J. Int. Soc. Oncodev. Biol. Med. 2013, 34, 1991-2002. [CrossRef] [PubMed]

145. Vanhaesebroeck, B.; Stephens, L.; Hawkins, P. PI3K Signalling: The Path to Discovery and Understanding. Nat. Rev. Mol. Cell Biol. 2012, 13, 195-203. [CrossRef] [PubMed]

146. Manning, B.D.; Cantley, L.C. AKT/PKB Signaling: Navigating Downstream. Cell 2007, 129, 1261-1274. [CrossRef] [PubMed]

147. Burke, J.E.; Williams, R.L. Synergy in Activating Class I PI3Ks. Trends Biochem. Sci. 2015, 40, 88-100. [CrossRef]

148. Laplante, M.; Sabatini, D.M. MTOR Signaling in Growth Control and Disease. Cell 2012, 149, 274-293. [CrossRef]

149. Popescu, A.M.; Purcaru, S.O.; Alexandru, O.; Dricu, A. New Perspectives in Glioblastoma Antiangiogenic Therapy. Contemp. Oncol. Pozn. Pol. 2016, 20, 109-118. [CrossRef]

150. Tan, X.; Apte, U.; Micsenyi, A.; Kotsagrelos, E.; Luo, J.-H.; Ranganathan, S.; Monga, D.K.; Bell, A.; Michalopoulos, G.K.; Monga, S.P.S. Epidermal Growth Factor Receptor: A Novel Target of the Wnt/Beta-Catenin Pathway in Liver. Gastroenterology 2005, 129, 285-302. [CrossRef]

151. Mora, A.; Komander, D.; van Aalten, D.M.F.; Alessi, D.R. PDK1, the Master Regulator of AGC Kinase Signal Transduction. Semin. Cell Dev. Biol. 2004, 15, 161-170. [CrossRef]

152. Loewith, R.; Hall, M.N. Target of Rapamycin (TOR) in Nutrient Signaling and Growth Control. Genetics 2011, $189,1177-1201$. [CrossRef]

153. Dibble, C.C.; Cantley, L.C. Regulation of MTORC1 by PI3K Signaling. Trends Cell Biol. 2015, 25, 545-555. [CrossRef]

154. Gan, X.; Wang, J.; Su, B.; Wu, D. Evidence for Direct Activation of MTORC2 Kinase Activity by Phosphatidylinositol 3,4,5Trisphosphate. J. Biol. Chem. 2011, 286, 10998-11002. [CrossRef]

155. Efeyan, A.; Sabatini, D.M. Nutrients and Growth Factors in MTORC1 Activation. Biochem. Soc. Trans. 2013, 41, 902-905. [CrossRef]

156. Le Sage, V.; Cinti, A.; Amorim, R.; Mouland, A.J. Adapting the Stress Response: Viral Subversion of the mTOR Signaling Pathway. Viruses 2016, 8, 152. [CrossRef]

157. Sato, T.; Nakashima, A.; Guo, L.; Tamanoi, F. Specific Activation of MTORC1 by Rheb G-Protein in Vitro Involves Enhanced Recruitment of Its Substrate Protein. J. Biol. Chem. 2009, 284, 12783-12791. [CrossRef]

158. Tabancay, A.P.; Gau, C.-L.; Machado, I.M.P.; Uhlmann, E.J.; Gutmann, D.H.; Guo, L.; Tamanoi, F. Identification of Dominant Negative Mutants of Rheb GTPase and Their Use to Implicate the Involvement of Human Rheb in the Activation of P70S6K. J. Biol. Chem. 2003, 278, 39921-39930. [CrossRef]

159. Tee, A.R.; Blenis, J.; Proud, C.G. Analysis of MTOR Signaling by the Small G-Proteins, Rheb and RhebL1. FEBS Lett. 2005, 579, 4763-4768. [CrossRef]

160. Dunlop, E.A.; Dodd, K.M.; Seymour, L.A.; Tee, A.R. Mammalian Target of Rapamycin Complex 1-Mediated Phosphorylation of Eukaryotic Initiation Factor 4E-Binding Protein 1 Requires Multiple Protein-Protein Interactions for Substrate Recognition. Cell. Signal. 2009, 21, 1073-1084. [CrossRef]

161. Howell, J.J.; Manning, B.D. MTOR Couples Cellular Nutrient Sensing to Organismal Metabolic Homeostasis. Trends Endocrinol. Metab. TEM 2011, 22, 94-102. [CrossRef]

162. Sarbassov, D.D.; Guertin, D.A.; Ali, S.M.; Sabatini, D.M. Phosphorylation and Regulation of Akt/PKB by the Rictor-MTOR Complex. Science 2005, 307, 1098-1101. [CrossRef]

163. Shanmugasundaram, K.; Block, K.; Nayak, B.K.; Livi, C.B.; Venkatachalam, M.A.; Sudarshan, S. PI3K Regulation of the SKP-2/P27 Axis through MTORC2. Oncogene 2013, 32, 2027-2036. [CrossRef]

164. Dan, H.C.; Antonia, R.J.; Baldwin, A.S. PI3K/Akt Promotes Feedforward MTORC2 Activation through IKK $\alpha$. Oncotarget 2016, 7 , 21064-21075. [CrossRef] [PubMed]

165. Fuhler, G.M.; Tyl, M.R.; Olthof, S.G.M.; Lyndsay Drayer, A.; Blom, N.; Vellenga, E. Distinct Roles of the MTOR Components Rictor and Raptor in MO7e Megakaryocytic Cells. Eur. J. Haematol. 2009, 83, 235-245. [CrossRef] [PubMed] 
166. Greijer, A.E.; van der Groep, P.; Kemming, D.; Shvarts, A.; Semenza, G.L.; Meijer, G.A.; van de Wiel, M.A.; Belien, J.a.M.; van Diest, P.J.; van der Wall, E. Up-Regulation of Gene Expression by Hypoxia Is Mediated Predominantly by Hypoxia-Inducible Factor 1 (HIF-1). J. Pathol. 2005, 206, 291-304. [CrossRef] [PubMed]

167. Berra, E.; Ginouvès, A.; Pouysségur, J. The Hypoxia-Inducible-Factor Hydroxylases Bring Fresh Air into Hypoxia Signalling. EMBO Rep. 2006, 7, 41-45. [CrossRef]

168. Kaelin, W.G. The von Hippel-Lindau Tumor Suppressor Protein: Roles in Cancer and Oxygen Sensing. Cold Spring Harb. Symp. Quant. Biol. 2005, 70, 159-166. [CrossRef]

169. Chen, Z.; Lu, W.; Garcia-Prieto, C.; Huang, P. The Warburg Effect and Its Cancer Therapeutic Implications. J. Bioenerg. Biomembr. 2007, 39, 267-274. [CrossRef]

170. Faure Vigny, H.; Heddi, A.; Giraud, S.; Chautard, D.; Stepien, G. Expression of Oxidative Phosphorylation Genes in Renal Tumors and Tumoral Cell Lines. Mol. Carcinog. 1996, 16, 165-172. [CrossRef]

171. Unwin, R.D.; Craven, R.A.; Harnden, P.; Hanrahan, S.; Totty, N.; Knowles, M.; Eardley, I.; Selby, P.J.; Banks, R.E. Proteomic Changes in Renal Cancer and Co-Ordinate Demonstration of Both the Glycolytic and Mitochondrial Aspects of the Warburg Effect. Proteomics 2003, 3, 1620-1632. [CrossRef]

172. Dekanty, A. The Insulin-PI3K/TOR Pathway Induces a HIF-Dependent Transcriptional Response in Drosophila by Promoting Nuclear Localization of HIF- /Sima. J. Cell Sci. 2005, 118, 5431-5441. [CrossRef]

173. Shaw, R.J. Glucose Metabolism and Cancer. Curr. Opin. Cell Biol. 2006, 18, 598-608. [CrossRef]

174. Brugarolas, J.B.; Vazquez, F.; Reddy, A.; Sellers, W.R.; Kaelin, W.G. TSC2 Regulates VEGF through MTOR-Dependent and -Independent Pathways. Cancer Cell 2003, 4, 147-158. [CrossRef]

175. Düvel, K.; Yecies, J.L.; Menon, S.; Raman, P.; Lipovsky, A.I.; Souza, A.L.; Triantafellow, E.; Ma, Q.; Gorski, R.; Cleaver, S.; et al. Activation of a Metabolic Gene Regulatory Network Downstream of MTOR Complex 1. Mol. Cell 2010, 39, 171-183. [CrossRef]

176. Land, S.C.; Tee, A.R. Hypoxia-Inducible Factor 1alpha Is Regulated by the Mammalian Target of Rapamycin (MTOR) via an MTOR Signaling Motif. J. Biol. Chem. 2007, 282, 20534-20543. [CrossRef]

177. Toschi, A.; Lee, E.; Gadir, N.; Ohh, M.; Foster, D.A. Differential Dependence of Hypoxia-Inducible Factors 1 Alpha and 2 Alpha on MTORC1 and MTORC2. J. Biol. Chem. 2008, 283, 34495-34499. [CrossRef]

178. Xu, Q.; Briggs, J.; Park, S.; Niu, G.; Kortylewski, M.; Zhang, S.; Gritsko, T.; Turkson, J.; Kay, H.; Semenza, G.L.; et al. Targeting Stat3 Blocks Both HIF-1 and VEGF Expression Induced by Multiple Oncogenic Growth Signaling Pathways. Oncogene 2005, 24, 5552-5560. [CrossRef]

179. McEwen, B.S.; Reagan, L.P. Glucose Transporter Expression in the Central Nervous System: Relationship to Synaptic Function. Eur. J. Pharmacol. 2004, 490, 13-24. [CrossRef]

180. Bos, R.; van Der Hoeven, J.J.M.; van Der Wall, E.; van Der Groep, P.; van Diest, P.J.; Comans, E.F.I.; Joshi, U.; Semenza, G.L.; Hoekstra, O.S.; Lammertsma, A.A.; et al. Biologic Correlates of (18)Fluorodeoxyglucose Uptake in Human Breast Cancer Measured by Positron Emission Tomography. J. Clin. Oncol. Off. J. Am. Soc. Clin. Oncol. 2002, 20, 379-387. [CrossRef]

181. Luo, W.; Semenza, G.L. Pyruvate Kinase M2 Regulates Glucose Metabolism by Functioning as a Coactivator for Hypoxia-Inducible Factor 1 in Cancer Cells. Oncotarget 2011, 2, 551-556. [CrossRef]

182. Strickland, M.; Stoll, E.A. Metabolic Reprogramming in Glioma. Front. Cell Dev. Biol. 2017, 5, 43. [CrossRef]

183. Pereira, K.M.A.; Chaves, F.N.; Viana, T.S.A.; Carvalho, F.S.R.; Costa, F.W.G.; Alves, A.P.N.N.; Sousa, F.B. Oxygen Metabolism in Oral Cancer: HIF and GLUTs (Review). Oncol. Lett. 2013, 6, 311-316. [CrossRef]

184. Shibuya, K.; Okada, M.; Suzuki, S.; Seino, M.; Seino, S.; Takeda, H.; Kitanaka, C. Targeting the Facilitative Glucose Transporter GLUT1 Inhibits the Self-Renewal and Tumor-Initiating Capacity of Cancer Stem Cells. Oncotarget 2015, 6, 651-661. [CrossRef]

185. Yang, W.; Zheng, Y.; Xia, Y.; Ji, H.; Chen, X.; Guo, F.; Lyssiotis, C.A.; Aldape, K.; Cantley, L.C.; Lu, Z. ERK1/2-Dependent Phosphorylation and Nuclear Translocation of PKM2 Promotes the Warburg Effect. Nat. Cell Biol. 2012, 14, 1295-1304. [CrossRef]

186. Mathupala, S.P.; Rempel, A.; Pedersen, P.L. Glucose Catabolism in Cancer Cells: Identification and Characterization of a Marked Activation Response of the Type II Hexokinase Gene to Hypoxic Conditions. J. Biol. Chem. 2001, 276, 43407-43412. [CrossRef]

187. Wolf, A.; Agnihotri, S.; Micallef, J.; Mukherjee, J.; Sabha, N.; Cairns, R.; Hawkins, C.; Guha, A. Hexokinase 2 Is a Key Mediator of Aerobic Glycolysis and Promotes Tumor Growth in Human Glioblastoma Multiforme. J. Exp. Med. 2011, 208, 313-326. [CrossRef]

188. Gershon, T.R.; Crowther, A.J.; Tikunov, A.; Garcia, I.; Annis, R.; Yuan, H.; Miller, C.R.; Macdonald, J.; Olson, J.; Deshmukh, M. Hexokinase-2-Mediated Aerobic Glycolysis Is Integral to Cerebellar Neurogenesis and Pathogenesis of Medulloblastoma. Cancer Metab. 2013, 1, 2. [CrossRef]

189. Imamura, K.; Tanaka, T. Multimolecular Forms of Pyruvate Kinase from Rat and Other Mammalian Tissues. I. Electrophoretic Studies. J. Biochem. 1972, 71, 1043-1051. [CrossRef]

190. Israelsen, W.J.; Dayton, T.L.; Davidson, S.M.; Fiske, B.P.; Hosios, A.M.; Bellinger, G.; Li, J.; Yu, Y.; Sasaki, M.; Horner, J.W.; et al. PKM2 Isoform-Specific Deletion Reveals a Differential Requirement for Pyruvate Kinase in Tumor Cells. Cell 2013, 155, 397-409. [CrossRef]

191. Mazurek, S. Pyruvate Kinase Type M2: A Key Regulator of the Metabolic Budget System in Tumor Cells. Int. J. Biochem. Cell Biol. 2011, 43, 969-980. [CrossRef] [PubMed]

192. Harris, R.A.; Tindale, L.; Cumming, R.C. Age-Dependent Metabolic Dysregulation in Cancer and Alzheimer's Disease. Biogerontology 2014, 15, 559-577. [CrossRef] [PubMed] 
193. Bao, L.; Kimzey, A.; Sauter, G.; Sowadski, J.M.; Lu, K.P.; Wang, D.-G. Prevalent Overexpression of Prolyl Isomerase Pin1 in Human Cancers. Am. J. Pathol. 2004, 164, 1727-1737. [CrossRef]

194. Ryo, A.; Nakamura, M.; Wulf, G.; Liou, Y.C.; Lu, K.P. Pin1 Regulates Turnover and Subcellular Localization of Beta-Catenin by Inhibiting Its Interaction with APC. Nat. Cell Biol. 2001, 3, 793-801. [CrossRef]

195. Yang, W.; Xia, Y.; Hawke, D.; Li, X.; Liang, J.; Xing, D.; Aldape, K.; Hunter, T.; Alfred Yung, W.K.; Lu, Z. PKM2 Phosphorylates Histone H3 and Promotes Gene Transcription and Tumorigenesis. Cell 2012, 150, 685-696. [CrossRef]

196. Roche, T.E.; Baker, J.C.; Yan, X.; Hiromasa, Y.; Gong, X.; Peng, T.; Dong, J.; Turkan, A.; Kasten, S.A. Distinct Regulatory Properties of Pyruvate Dehydrogenase Kinase and Phosphatase Isoforms. Prog. Nucleic Acid Res. Mol. Biol. 2001, 70, $33-75$.

197. Burgner, J.W.; Ray, W.J. On the Origin of the Lactate Dehydrogenase Induced Rate Effect. Biochemistry 1984, $23,3636-3648$. [CrossRef]

198. Kumar, V.B.S.; Viji, R.I.; Kiran, M.S.; Sudhakaran, P.R. Endothelial Cell Response to Lactate: Implication of PAR Modification of VEGF. J. Cell. Physiol. 2007, 211, 477-485. [CrossRef]

199. Porporato, P.E.; Payen, V.L.; De Saedeleer, C.J.; Préat, V.; Thissen, J.-P.; Feron, O.; Sonveaux, P. Lactate Stimulates Angiogenesis and Accelerates the Healing of Superficial and Ischemic Wounds in Mice. Angiogenesis 2012, 15, 581-592. [CrossRef]

200. Valvona, C.J.; Fillmore, H.L.; Nunn, P.B.; Pilkington, G.J. The Regulation and Function of Lactate Dehydrogenase A: Therapeutic Potential in Brain Tumor. Brain Pathol. 2016, 26, 3-17. [CrossRef]

201. Kim, J.; Dang, C.V. Cancer's Molecular Sweet Tooth and the Warburg Effect. Cancer Res. 2006, 66, 8927-8930. [CrossRef]

202. Firth, J.D.; Ebert, B.L.; Ratcliffe, P.J. Hypoxic Regulation of Lactate Dehydrogenase A. Interaction between Hypoxia-Inducible Factor 1 and CAMP Response Elements. J. Biol. Chem. 1995, 270, 21021-21027. [CrossRef]

203. Lewis, B.C.; Shim, H.; Li, Q.; Wu, C.S.; Lee, L.A.; Maity, A.; Dang, C.V. Identification of Putative C-Myc-Responsive Genes: Characterization of Rcl, a Novel Growth-Related Gene. Mol. Cell. Biol. 1997, 17, 4967-4978. [CrossRef]

204. Semenza, G.L.; Jiang, B.H.; Leung, S.W.; Passantino, R.; Concordet, J.P.; Maire, P.; Giallongo, A. Hypoxia Response Elements in the Aldolase A, Enolase 1, and Lactate Dehydrogenase A Gene Promoters Contain Essential Binding Sites for Hypoxia-Inducible Factor 1. J. Biol. Chem. 1996, 271, 32529-32537. [CrossRef]

205. Shim, H.; Dolde, C.; Lewis, B.C.; Wu, C.S.; Dang, G.; Jungmann, R.A.; Dalla-Favera, R.; Dang, C.V. C-Myc Transactivation of LDH-A: Implications for Tumor Metabolism and Growth. Proc. Natl. Acad. Sci. USA 1997, 94, 6658-6663. [CrossRef]

206. Brooks, G.A. Lactate Shuttles in Nature. Biochem. Soc. Trans. 2002, 30, 258-264. [CrossRef]

207. Koukourakis, M.I.; Giatromanolaki, A.; Sivridis, E.; Bougioukas, G.; Didilis, V.; Gatter, K.C.; Harris, A.L. Tumour and Angiogenesis Research Group Lactate Dehydrogenase-5 (LDH-5) Overexpression in Non-Small-Cell Lung Cancer Tissues Is Linked to Tumour Hypoxia, Angiogenic Factor Production and Poor Prognosis. Br. J. Cancer 2003, 89, 877-885. [CrossRef]

208. Koukourakis, M.I.; Giatromanolaki, A.; Sivridis, E.; Gatter, K.C.; Trarbach, T.; Folprecht, G.; Shi, M.M.; Lebwohl, D.; Jalava, T.; Laurent, D.; et al. Prognostic and Predictive Role of Lactate Dehydrogenase 5 Expression in Colorectal Cancer Patients Treated with PTK787/ZK 222584 (Vatalanib) Antiangiogenic Therapy. Clin. Cancer Res. Off. J. Am. Assoc. Cancer Res. 2011, 17, 4892-4900. [CrossRef]

209. Beckert, S.; Farrahi, F.; Aslam, R.S.; Scheuenstuhl, H.; Königsrainer, A.; Hussain, M.Z.; Hunt, T.K. Lactate Stimulates Endothelial Cell Migration. Wound Repair Regen. Off. Publ. Wound Heal. Soc. Eur. Tissue Repair Soc. 2006, 14, 321-324. [CrossRef]

210. Hirschhaeuser, F.; Sattler, U.G.A.; Mueller-Klieser, W. Lactate: A Metabolic Key Player in Cancer. Cancer Res. 2011, 71, 6921-6925. [CrossRef]

211. Xu, L.; Fidler, I.J. Acidic PH-Induced Elevation in Interleukin 8 Expression by Human Ovarian Carcinoma Cells. Cancer Res. 2000, 60, 4610-4616. [PubMed]

212. Brohée, L.; Peulen, O.; Nusgens, B.; Castronovo, V.; Thiry, M.; Colige, A.C.; Deroanne, C.F. Propranolol Sensitizes Prostate Cancer Cells to Glucose Metabolism Inhibition and Prevents Cancer Progression. Sci. Rep. 2018, 8, 7050. [CrossRef] [PubMed]

213. Chen, Y.; Dai, X.; Yao, Y.; Wang, J.; Yang, X.; Zhang, Y.; Yang, J.; Cao, R.; Wen, G.; Zhong, J. PRMT2 $\beta$ Suppresses Autophagy and Glycolysis Pathway in Human Breast Cancer MCF-7 Cell Lines. Acta Biochim. Biophys. Sin. 2019, 51, 335-337. [CrossRef] [PubMed]

214. Ryskalin, L.; Gaglione, A.; Limanaqi, F.; Biagioni, F.; Familiari, P.; Frati, A.; Esposito, V.; Fornai, F. The Autophagy Status of Cancer Stem Cells in Gliobastoma Multiforme: From Cancer Promotion to Therapeutic Strategies. Int. J. Mol. Sci. 2019, 20, 3824. [CrossRef] [PubMed]

215. Lorzadeh, S.; Kohan, L.; Ghavami, S.; Azarpira, N. Autophagy and the Wnt Signaling Pathway: A Focus on Wnt/ $\beta$-Catenin Signaling. Biochim. Biophys. Acta Mol. Cell Res. 2020, 1868, 118926. [CrossRef] [PubMed]

216. Yin, Z.; Pascual, C.; Klionsky, D.J. Autophagy: Machinery and Regulation. Microb. Cell 2016, 3, 588-596. [CrossRef]

217. Kohler, V.; Aufschnaiter, A.; Büttner, S. Closing the Gap: Membrane Contact Sites in the Regulation of Autophagy. Cells 2020, 9 , 1184. [CrossRef]

218. Yim, W.W.-Y.; Mizushima, N. Lysosome Biology in Autophagy. Cell Discov. 2020, 6, 6. [CrossRef]

219. Alizadeh, J.; Shojaei, S.; Sepanjnia, A.; Hashemi, M.; Eftekharpour, E.; Ghavami, S. Simultaneous Detection of Autophagy and Epithelial to Mesenchymal Transition in the Non-Small Cell Lung Cancer Cells. Methods Mol. Biol. 2019, 1854, 87-103. [CrossRef]

220. Brun, P.; Tarricone, E.; Di Stefano, A.; Mattiuzzo, E.; Mehrbod, P.; Ghavami, S.; Leonardi, A. The Regulatory Activity of Autophagy in Conjunctival Fibroblasts and Its Possible Role in Vernal Keratoconjunctivitis. J. Allergy Clin. Immunol. 2020, 146, 1210-1213.e9. [CrossRef] 
221. Wasik, A.M.; Grabarek, J.; Pantovic, A.; Cieślar-Pobuda, A.; Asgari, H.R.; Bundgaard-Nielsen, C.; Rafat, M.; Dixon, I.M.C.; Ghavami, S.; Łos, M.J. Reprogramming and Carcinogenesis-Parallels and Distinctions. Int. Rev. Cell Mol. Biol. 2014, 308, 167-203. [CrossRef]

222. Kardideh, B.; Samimi, Z.; Norooznezhad, F.; Kiani, S.; Mansouri, K. Autophagy, Cancer and Angiogenesis: Where Is the Link? Cell Biosci. 2019, 9, 65. [CrossRef]

223. Ghavami, S.; Shojaei, S.; Yeganeh, B.; Ande, S.R.; Jangamreddy, J.R.; Mehrpour, M.; Christoffersson, J.; Chaabane, W.; Moghadam, A.R.; Kashani, H.H.; et al. Autophagy and Apoptosis Dysfunction in Neurodegenerative Disorders. Prog. Neurobiol. 2014, 112, 24-49. [CrossRef]

224. Rautou, P.-E.; Mansouri, A.; Lebrec, D.; Durand, F.; Valla, D.; Moreau, R. Autophagy in Liver Diseases. J. Hepatol. 2010, 53, 1123-1134. [CrossRef]

225. Martinez-Lopez, N.; Athonvarangkul, D.; Singh, R. Autophagy and Aging. Adv. Exp. Med. Biol. 2015, 847, 73-87. [CrossRef]

226. Ren, L.; Yang, H.; Cui, Y.; Xu, S.; Sun, F.; Tian, N.; Hua, J.; Peng, S. Autophagy Is Essential for the Differentiation of Porcine PSCs into Insulin-Producing Cells. Biochem. Biophys. Res. Commun. 2017, 488, 471-476. [CrossRef]

227. White, E. Deconvoluting the Context-Dependent Role for Autophagy in Cancer. Nat. Rev. Cancer 2012, 12, 401-410. [CrossRef]

228. Poillet-Perez, L.; White, E. Role of Tumor and Host Autophagy in Cancer Metabolism. Genes Dev. 2019, 33, 610-619. [CrossRef]

229. Takamura, A.; Komatsu, M.; Hara, T.; Sakamoto, A.; Kishi, C.; Waguri, S.; Eishi, Y.; Hino, O.; Tanaka, K.; Mizushima, N. Autophagy-Deficient Mice Develop Multiple Liver Tumors. Genes Dev. 2011, 25, 795-800. [CrossRef]

230. Qu, X.; Yu, J.; Bhagat, G.; Furuya, N.; Hibshoosh, H.; Troxel, A.; Rosen, J.; Eskelinen, E.-L.; Mizushima, N.; Ohsumi, Y.; et al. Promotion of Tumorigenesis by Heterozygous Disruption of the Beclin 1 Autophagy Gene. J. Clin. Investig. 2003, 112, 1809-1820. [CrossRef]

231. Kocaturk, N.M.; Akkoc, Y.; Kig, C.; Bayraktar, O.; Gozuacik, D.; Kutlu, O. Autophagy as a Molecular Target for Cancer Treatment. Eur. J. Pharm. Sci. Off. J. Eur. Fed. Pharm. Sci. 2019, 134, 116-137. [CrossRef]

232. Levine, B.; Kroemer, G. Biological Functions of Autophagy Genes: A Disease Perspective. Cell 2019, 176, 11-42. [CrossRef]

233. Mulcahy Levy, J.M.; Towers, C.G.; Thorburn, A. Targeting Autophagy in Cancer. Nat. Rev. Cancer 2017, 17, 528-542. [CrossRef]

234. Nassour, J.; Radford, R.; Correia, A.; Fusté, J.M.; Schoell, B.; Jauch, A.; Shaw, R.J.; Karlseder, J. Autophagic Cell Death Restricts Chromosomal Instability during Replicative Crisis. Nature 2019, 565, 659-663. [CrossRef] [PubMed]

235. Goussetis, D.J.; Gounaris, E.; Wu, E.J.; Vakana, E.; Sharma, B.; Bogyo, M.; Altman, J.K.; Platanias, L.C. Autophagic Degradation of the BCR-ABL Oncoprotein and Generation of Antileukemic Responses by Arsenic Trioxide. Blood 2012, 120, 3555-3562. [CrossRef] [PubMed]

236. Yang, A.; Kimmelman, A.C. Inhibition of Autophagy Attenuates Pancreatic Cancer Growth Independent of TP53/TRP53 Status. Autophagy 2014, 10, 1683-1684. [CrossRef] [PubMed]

237. Guo, J.Y.; Teng, X.; Laddha, S.V.; Ma, S.; Van Nostrand, S.C.; Yang, Y.; Khor, S.; Chan, C.S.; Rabinowitz, J.D.; White, E. Autophagy Provides Metabolic Substrates to Maintain Energy Charge and Nucleotide Pools in Ras-Driven Lung Cancer Cells. Genes Dev. 2016, 30, 1704-1717. [CrossRef]

238. Akkoç, Y.; Berrak, Ö.; Arısan, E.D.; Obakan, P.; Çoker-Gürkan, A.; Palavan-Ünsal, N. Inhibition of PI3K Signaling Triggered Apoptotic Potential of Curcumin Which Is Hindered by Bcl-2 through Activation of Autophagy in MCF-7 Cells. Biomed. Pharmacother. 2015, 71, 161-171. [CrossRef]

239. Chen, W.; Bai, Y.; Patel, C.; Geng, F. Autophagy Promotes Triple Negative Breast Cancer Metastasis via YAP Nuclear Localization. Biochem. Biophys. Res. Commun. 2019, 520, 263-268. [CrossRef]

240. Kawaguchi, M.; Aoki, S.; Hirao, T.; Morita, M.; Ito, K. Autophagy Is an Important Metabolic Pathway to Determine Leukemia Cell Survival Following Suppression of the Glycolytic Pathway. Biochem. Biophys. Res. Commun. 2016, 474, 188-192. [CrossRef]

241. Wang, X.; Lu, S.; He, C.; Wang, C.; Wang, L.; Piao, M.; Chi, G.; Luo, Y.; Ge, P. RSL3 Induced Autophagic Death in Glioma Cells via Causing Glycolysis Dysfunction. Biochem. Biophys. Res. Commun. 2019, 518, 590-597. [CrossRef]

242. Kim, J.H.; Nam, B.; Choi, Y.J.; Kim, S.Y.; Lee, J.-E.; Sung, K.J.; Kim, W.S.; Choi, C.-M.; Chang, E.-J.; Koh, J.S.; et al. Enhanced Glycolysis Supports Cell Survival in EGFR-Mutant Lung Adenocarcinoma by Inhibiting Autophagy-Mediated EGFR Degradation. Cancer Res. 2018, 78, 4482-4496. [CrossRef]

243. Zhang, X.-Y.; Zhang, M.; Cong, Q.; Zhang, M.-X.; Zhang, M.-Y.; Lu, Y.-Y.; Xu, C.-J. Hexokinase 2 Confers Resistance to Cisplatin in Ovarian Cancer Cells by Enhancing Cisplatin-Induced Autophagy. Int. J. Biochem. Cell Biol. 2018, 95, 9-16. [CrossRef]

244. Hardie, D.G.; Ross, F.A.; Hawley, S.A. AMPK: A Nutrient and Energy Sensor That Maintains Energy Homeostasis. Nat. Rev. Mol. Cell Biol. 2012, 13, 251-262. [CrossRef]

245. Takai, T.; Tsujino, T.; Yoshikawa, Y.; Inamoto, T.; Sugito, N.; Kuranaga, Y.; Heishima, K.; Soga, T.; Hayashi, K.; Miyata, K.; et al. Synthetic MiR-143 Exhibited an Anti-Cancer Effect via the Downregulation of K-RAS Networks of Renal Cell Cancer Cells In Vitro and In Vivo. Mol. Ther. J. Am. Soc. Gene Ther. 2019, 27, 1017-1027. [CrossRef]

246. Wu, X.; Won, H.; Rubinsztein, D.C. Autophagy and Mammalian Development. Biochem. Soc. Trans. 2013, 41, 1489-1494. [CrossRef]

247. Petherick, K.J.; Williams, A.C.; Lane, J.D.; Ordóñez-Morán, P.; Huelsken, J.; Collard, T.J.; Smartt, H.J.M.; Batson, J.; Malik, K.; Paraskeva, C.; et al. Autolysosomal $\beta$-Catenin Degradation Regulates Wnt-Autophagy-P62 Crosstalk. EMBO J. 2013, 32, 1903-1916. [CrossRef] 
248. Tao, H.; Chen, F.; Liu, H.; Hu, Y.; Wang, Y.; Li, H. Wnt/ $\beta$-Catenin Signaling Pathway Activation Reverses Gemcitabine Resistance by Attenuating Beclin1-Mediated Autophagy in the MG63 Human Osteosarcoma Cell Line. Mol. Med. Rep. 2017, 16, 1701-1706. [CrossRef]

249. Gao, C.; Cao, W.; Bao, L.; Zuo, W.; Xie, G.; Cai, T.; Fu, W.; Zhang, J.; Wu, W.; Zhang, X.; et al. Autophagy Negatively Regulates Wnt Signalling by Promoting Dishevelled Degradation. Nat. Cell Biol. 2010, 12, 781-790. [CrossRef]

250. Hoverter, N.P.; Waterman, M.L. A Wnt-Fall for Gene Regulation: Repression. Sci. Signal. 2008, 1, pe43. [CrossRef]

251. Nàger, M.; Sallán, M.C.; Visa, A.; Pushparaj, C.; Santacana, M.; Macià, A.; Yeramian, A.; Cantí, C.; Herreros, J. Inhibition of WNT-CTNNB1 Signaling Upregulates SQSTM1 and Sensitizes Glioblastoma Cells to Autophagy Blockers. Autophagy 2018, 14, 619-636. [CrossRef] [PubMed]

252. Komiya, Y.; Habas, R. Wnt Signal Transduction Pathways. Organogenesis 2008, 4, 68-75. [CrossRef] [PubMed]

253. Hwang, S.-H.; Bang, S.; Kang, K.S.; Kang, D.; Chung, J. ULK1 Negatively Regulates Wnt Signaling by Phosphorylating Dishevelled. Biochem. Biophys. Res. Commun. 2019, 508, 308-313. [CrossRef] [PubMed]

254. Colella, B.; Faienza, F.; Carinci, M.; D’Alessandro, G.; Catalano, M.; Santoro, A.; Cecconi, F.; Limatola, C.; Di Bartolomeo, S. Autophagy Induction Impairs Wnt $\beta$-Catenin Signalling through $\beta$-Catenin Relocalisation in Glioblastoma Cells. Cell. Signal. 2019, 53, 357-364. [CrossRef]

255. Zhong, Z.; Yu, J.; Virshup, D.M.; Madan, B. Wnts and the Hallmarks of Cancer. Cancer Metastasis Rev. 2020, 39, 625-645. [CrossRef]

256. Hermida, M.A.; Dinesh Kumar, J.; Leslie, N.R. GSK3 and Its Interactions with the PI3K/AKT/MTOR Signalling Network. Adv. Biol. Regul. 2017, 65, 5-15. [CrossRef]

257. Buttrick, G.J.; Wakefield, J.G. PI3-K and GSK-3: Akt-Ing Together with Microtubules. Cell Cycle Georget. Tex 2008, 7, $2621-2625$. [CrossRef]

258. Cheng, X.; Ma, X.; Zhu, Q.; Song, D.; Ding, X.; Li, L.; Jiang, X.; Wang, X.; Tian, R.; Su, H.; et al. Pacer Is a Mediator of MTORC1 and GSK3-TIP60 Signaling in Regulation of Autophagosome Maturation and Lipid Metabolism. Mol. Cell 2019, 73, 788-802.e7. [CrossRef]

259. Aznar, N.; Sun, N.; Dunkel, Y.; Ear, J.; Buschman, M.D.; Ghosh, P. A Daple-Akt Feed-Forward Loop Enhances Noncanonical Wnt Signals by Compartmentalizing $\beta$-Catenin. Mol. Biol. Cell 2017, 28, 3709-3723. [CrossRef]

260. Pérez-Plasencia, C.; López-Urrutia, E.; García-Castillo, V.; Trujano-Camacho, S.; López-Camarillo, C.; Campos-Parra, A.D. Interplay Between Autophagy and Wnt/ $\beta$-Catenin Signaling in Cancer: Therapeutic Potential Through Drug Repositioning. Front. Oncol. 2020, 10, 1037. [CrossRef]

261. Fan, Q.; Yang, L.; Zhang, X.; Ma, Y.; Li, Y.; Dong, L.; Zong, Z.; Hua, X.; Su, D.; Li, H.; et al. Autophagy Promotes Metastasis and Glycolysis by Upregulating MCT1 Expression and Wnt/ $\beta$-Catenin Signaling Pathway Activation in Hepatocellular Carcinoma Cells. J. Exp. Clin. Cancer Res. 2018, 37, 9. [CrossRef]

262. Jing, Q.; Li, G.; Chen, X.; Liu, C.; Lu, S.; Zheng, H.; Ma, H.; Qin, Y.; Zhang, D.; Zhang, S.; et al. Wnt3a Promotes Radioresistance via Autophagy in Squamous Cell Carcinoma of the Head and Neck. J. Cell. Mol. Med. 2019, 23, 4711-4722. [CrossRef]

263. DeBerardinis, R.J.; Mancuso, A.; Daikhin, E.; Nissim, I.; Yudkoff, M.; Wehrli, S.; Thompson, C.B. Beyond Aerobic Glycolysis: Transformed Cells Can Engage in Glutamine Metabolism That Exceeds the Requirement for Protein and Nucleotide Synthesis. Proc. Natl. Acad. Sci. USA 2007, 104, 19345-19350. [CrossRef]

264. Yang, L.; Moss, T.; Mangala, L.S.; Marini, J.; Zhao, H.; Wahlig, S.; Armaiz-Pena, G.; Jiang, D.; Achreja, A.; Win, J.; et al. Metabolic Shifts toward Glutamine Regulate Tumor Growth, Invasion and Bioenergetics in Ovarian Cancer. Mol. Syst. Biol. 2014, 10, 728. [CrossRef]

265. Van Geldermalsen, M.; Wang, Q.; Nagarajah, R.; Marshall, A.D.; Thoeng, A.; Gao, D.; Ritchie, W.; Feng, Y.; Bailey, C.G.; Deng, N.; et al. ASCT2/SLC1A5 Controls Glutamine Uptake and Tumour Growth in Triple-Negative Basal-like Breast Cancer. Oncogene 2016, 35, 3201-3208. [CrossRef]

266. Kung, H.-N.; Marks, J.R.; Chi, J.-T. Glutamine Synthetase Is a Genetic Determinant of Cell Type-Specific Glutamine Independence in Breast Epithelia. PLoS Genet. 2011, 7, e1002229. [CrossRef]

267. Wang, J.-B.; Erickson, J.W.; Fuji, R.; Ramachandran, S.; Gao, P.; Dinavahi, R.; Wilson, K.F.; Ambrosio, A.L.B.; Dias, S.M.G.; Dang, C.V.; et al. Targeting Mitochondrial Glutaminase Activity Inhibits Oncogenic Transformation. Cancer Cell 2010, 18, 207-219. [CrossRef]

268. Son, J.; Lyssiotis, C.A.; Ying, H.; Wang, X.; Hua, S.; Ligorio, M.; Perera, R.M.; Ferrone, C.R.; Mullarky, E.; Shyh-Chang, N.; et al. Glutamine Supports Pancreatic Cancer Growth through a KRAS-Regulated Metabolic Pathway. Nature 2013, 496, 101-105. [CrossRef]

269. Li, C.; Zhang, G.; Zhao, L.; Ma, Z.; Chen, H. Metabolic Reprogramming in Cancer Cells: Glycolysis, Glutaminolysis, and Bcl-2 Proteins as Novel Therapeutic Targets for Cancer. World J. Surg. Oncol. 2016, 14, 15. [CrossRef]

270. Cadoret, A.; Ovejero, C.; Terris, B.; Souil, E.; Lévy, L.; Lamers, W.H.; Kitajewski, J.; Kahn, A.; Perret, C. New Targets of Beta-Catenin Signaling in the Liver Are Involved in the Glutamine Metabolism. Oncogene 2002, 21, 8293-8301. [CrossRef]

271. Gao, P.; Tchernyshyov, I.; Chang, T.-C.; Lee, Y.-S.; Kita, K.; Ochi, T.; Zeller, K.I.; De Marzo, A.M.; Van Eyk, J.E.; Mendell, J.T.; et al. C-Myc Suppression of MiR-23a/b Enhances Mitochondrial Glutaminase Expression and Glutamine Metabolism. Nature 2009, 458, 762-765. [CrossRef]

272. Wu, H.; Li, Z.; Yang, P.; Zhang, L.; Fan, Y.; Li, Z. PKM2 Depletion Induces the Compensation of Glutaminolysis through $\beta$-Catenin/c-Myc Pathway in Tumor Cells. Cell. Signal. 2014, 26, 2397-2405. [CrossRef] 
273. Godwin, A.K.; Meister, A.; O’Dwyer, P.J.; Huang, C.S.; Hamilton, T.C.; Anderson, M.E. High Resistance to Cisplatin in Human Ovarian Cancer Cell Lines Is Associated with Marked Increase of Glutathione Synthesis. Proc. Natl. Acad. Sci. USA 1992, 89, 3070-3074. [CrossRef]

274. Ishimoto, T.; Nagano, O.; Yae, T.; Tamada, M.; Motohara, T.; Oshima, H.; Oshima, M.; Ikeda, T.; Asaba, R.; Yagi, H.; et al. CD44 Variant Regulates Redox Status in Cancer Cells by Stabilizing the XCT Subunit of System Xc(-) and Thereby Promotes Tumor Growth. Cancer Cell 2011, 19, 387-400. [CrossRef]

275. Liao, J.; Liu, P.-P.; Hou, G.; Shao, J.; Yang, J.; Liu, K.; Lu, W.; Wen, S.; Hu, Y.; Huang, P. Regulation of Stem-like Cancer Cells by Glutamine through $\beta$-Catenin Pathway Mediated by Redox Signaling. Mol. Cancer 2017, 16, 51. [CrossRef]

276. Mihm, S.; Galter, D.; Dröge, W. Modulation of Transcription Factor NF Kappa B Activity by Intracellular Glutathione Levels and by Variations of the Extracellular Cysteine Supply. FASEB J. Off. Publ. Fed. Am. Soc. Exp. Biol. 1995, 9, 246-252. [CrossRef]

277. Miran, T.; Vogg, A.T.J.; Drude, N.; Mottaghy, F.M.; Morgenroth, A. Modulation of Glutathione Promotes Apoptosis in TripleNegative Breast Cancer Cells. FASEB J. Off. Publ. Fed. Am. Soc. Exp. Biol. 2018, 32, 2803-2813. [CrossRef]

278. Piersma, B.; Bank, R.A.; Boersema, M. Signaling in Fibrosis: TGF- $\beta$, WNT, and YAP/TAZ Converge. Front. Med. 2015,2 , 59. [CrossRef]

279. Azzolin, L.; Zanconato, F.; Bresolin, S.; Forcato, M.; Basso, G.; Bicciato, S.; Cordenonsi, M.; Piccolo, S. Role of TAZ as Mediator of Wnt Signaling. Cell 2012, 151, 1443-1456. [CrossRef]

280. Azzolin, L.; Panciera, T.; Soligo, S.; Enzo, E.; Bicciato, S.; Dupont, S.; Bresolin, S.; Frasson, C.; Basso, G.; Guzzardo, V.; et al YAP/TAZ Incorporation in the $\beta$-Catenin Destruction Complex Orchestrates the Wnt Response. Cell 2014, 158, 157-170. [CrossRef]

281. Lee, Y.; Kim, N.H.; Cho, E.S.; Yang, J.H.; Cha, Y.H.; Kang, H.E.; Yun, J.S.; Cho, S.B.; Lee, S.-H.; Paclikova, P.; et al. Dishevelled Has a YAP Nuclear Export Function in a Tumor Suppressor Context-Dependent Manner. Nat. Commun. 2018, 9, 2301. [CrossRef] [PubMed]

282. Park, H.W.; Kim, Y.C.; Yu, B.; Moroishi, T.; Mo, J.-S.; Plouffe, S.W.; Meng, Z.; Lin, K.C.; Yu, F.-X.; Alexander, C.M.; et al. Alternative Wnt Signaling Activates YAP/TAZ. Cell 2015, 162, 780-794. [CrossRef] [PubMed]

283. Konsavage, W.M.; Kyler, S.L.; Rennoll, S.A.; Jin, G.; Yochum, G.S. Wnt/ $\beta$-Catenin Signaling Regulates Yes-Associated Protein (YAP) Gene Expression in Colorectal Carcinoma Cells. J. Biol. Chem. 2012, 287, 11730-11739. [CrossRef] [PubMed]

284. Carthy, J.M.; Garmaroudi, F.S.; Luo, Z.; McManus, B.M. Wnt3a Induces Myofibroblast Differentiation by Upregulating TGF- $\beta$ Signaling through SMAD2 in a $\beta$-Catenin-Dependent Manner. PLoS ONE 2011, 6, e19809. [CrossRef]

285. Varelas, X.; Sakuma, R.; Samavarchi-Tehrani, P.; Peerani, R.; Rao, B.M.; Dembowy, J.; Yaffe, M.B.; Zandstra, P.W.; Wrana, J.L. TAZ Controls Smad Nucleocytoplasmic Shuttling and Regulates Human Embryonic Stem-Cell Self-Renewal. Nat. Cell Biol. 2008, 10, 837-848. [CrossRef]

286. Cox, A.G.; Hwang, K.L.; Brown, K.K.; Evason, K.; Beltz, S.; Tsomides, A.; O'Connor, K.; Galli, G.G.; Yimlamai, D.; Chhangawala, S.; et al. Yap Reprograms Glutamine Metabolism to Increase Nucleotide Biosynthesis and Enable Liver Growth. Nat. Cell Biol. 2016, 18, 886-896. [CrossRef]

287. Zhang, X.; Zhao, H.; Li, Y.; Xia, D.; Yang, L.; Ma, Y.; Li, H. The Role of YAP/TAZ Activity in Cancer Metabolic Reprogramming. Mol. Cancer 2018, 17, 134. [CrossRef]

288. Bertero, T.; Oldham, W.M.; Cottrill, K.A.; Pisano, S.; Vanderpool, R.R.; Yu, Q.; Zhao, J.; Tai, Y.; Tang, Y.; Zhang, Y.-Y.; et al. Vascular Stiffness Mechanoactivates YAP/TAZ-Dependent Glutaminolysis to Drive Pulmonary Hypertension. J. Clin. Investig. 2016, 126, 3313-3335. [CrossRef]

289. Zhao, B.; Wei, X.; Li, W.; Udan, R.S.; Yang, Q.; Kim, J.; Xie, J.; Ikenoue, T.; Yu, J.; Li, L.; et al. Inactivation of YAP Oncoprotein by the Hippo Pathway Is Involved in Cell Contact Inhibition and Tissue Growth Control. Genes Dev. 2007, 21, 2747-2761. [CrossRef]

290. Wang, W.; Xiao, Z.-D.; Li, X.; Aziz, K.E.; Gan, B.; Johnson, R.L.; Chen, J. AMPK Modulates Hippo Pathway Activity to Regulate Energy Homeostasis. Nat. Cell Biol. 2015, 17, 490-499. [CrossRef]

291. Song, L.; Tang, H.; Liao, W.; Luo, X.; Li, Y.; Chen, T.; Zhang, X. FOXC2 Positively Regulates YAP Signaling and Promotes the Glycolysis of Nasopharyngeal Carcinoma. Exp. Cell Res. 2017, 357, 17-24. [CrossRef] 